Johnson, et al., in press, Earth Surface Processes and Landforms

\title{
Recent Shifts in Coastline Change and Shoreline Stabilization Linked to Storm Climate Change
}

Jennifer M. Johnson ${ }^{1}$, Laura J. Moore ${ }^{1 *}$, Kenneth Ells ${ }^{2}$, A. Brad Murray ${ }^{2}$, Peter N. Adams ${ }^{3}$, Richard A. MacKenzie ${ }^{3}$ III, and John M. Jaeger ${ }^{3}$

${ }^{1}$ Department of Geological Sciences, Coastal Environmental Change Lab, University of North Carolina, Chapel Hill, NC, USA

${ }^{2}$ Division of Earth and Ocean Sciences, Nicholas School of the Environment; Center for Nonlinear and Complex Systems, Duke University, Durham, NC, USA

${ }^{3}$ Department of Geological Sciences, University of Florida, Gainesville, FL, USA

\section{ABSTRACT}

Because cuspate coastlines are especially sensitive to changes in wave climate, they serve as potential indicators of initial responses to changing wave conditions. Previous work demonstrates that Cape Hatteras and Cape Lookout, NC, which are largely unaffected by shoreline stabilization efforts, have become increasingly asymmetric over the past 30 years, consistent with model predictions for coastline response to increases in Atlantic Ocean summer wave heights and resulting changes in the distribution of wave-approach angles. Historic and recent shoreline change observations for Cape Fear, North Carolina, and model simulations of coastline response to an increasingly asymmetric wave climate in the presence of beach nourishment, produce comparable differences in shoreline change rates in response to changes in wave climate. Results suggest that the effect of beach nourishment is to compensate for - and therefore to mask - natural responses to wave climate change that might otherwise be discernible in patterns of shoreline change alone. Therefore, this case study suggests that the effects of wave climate change on human-modified coastlines may be detectable in the spatial and temporal patterns of shoreline stabilization activities. Similar analyses of cuspate features in areas where the change in wave climate is less pronounced (i.e., Fishing Point, Maryland/Virginia) and where local geology appears to exert control on 
coastline shape (i.e., Cape Canaveral, Florida), suggest that changes in shoreline configuration that may be arising from shifting wave climate are currently limited to sandy wave-dominated coastlines where the change in wave climate has been most pronounced. However, if hurricane-generated wave heights continue to increase, large-scale shifts in patterns of erosion and accretion will likely extend beyond sensitive cuspate features as the larger-scale coastline shape comes into equilibrium with changing wave conditions.

\section{Introduction}

Coastal environments are highly dynamic, changing dramatically across a range of temporal and spatial scales in response to natural processes and modifications of the environment by humans. Climate change will influence coastal evolution by increasing sea level rise rates (IPCC, 2014), and potentially by increasing the frequency of intense hurricanes (e.g., Webster $e t$ al., 2005, Knutson et al., 2010, Emanuel, 2013). Whether or not hurricane activity changes, predicted increases in the rate of sea-level rise over the next century will lead to increases in storm impacts (Woodruff et al., 2013), likely resulting in increasing rates of landward migration of barrier islands (e.g., FitzGerald et al., 2008; Moore et al., 2010). As storm behaviors change (in response to climate change, or otherwise, e.g., Bromirski and Kossin, 2008), consequent changes in ocean wave climate (e.g., Cox and Swail, 2001; Sterl and Caires, 2005; Komar and Allan, 2008), may alter alongshore sediment transport gradients causing shifts in erosion hazard areas (Ruggiero et al., 2010; Adams et al., 2011; Moore et al., 2013). As coastlines change in response to these forcings, the tendency for humans to exert influence on coastal dynamics is also likely to increase (e.g., McNamara and Keeler, 2013; Hapke et al., 2013).

Approximately $13 \%$ of the world's urban areas - including an estimated 634 million inhabitants - are located in low-elevation coastal zones (McGranahan et al., 2007). Consequently, humans have employed many techniques to mitigate the effects of rising sea level and storms. 
These techniques, including shoreline armoring, beach nourishment and artificial dune construction, often have adverse effects that significantly alter sediment fluxes and the natural migration of coastal environments (e.g., Pilkey et al., 1998; Magliocca et al., 2011; Slott et al. 2010; Ells and Murray, 2012). It is increasingly important to understand the coupled naturalhuman processes that alter coastline evolution as global climate continues to change.

Here, using case-study examples from the U.S. East Coast (i.e., Cape Fear, North Carolina; Fishing Point, Maryland and Virginia; and Cape Canaveral, Florida), we further address the questions of how coastline morphology responds to changing climate forcing, and how coupled human/coastline systems on developed coastlines respond, when local shoreline stabilization prevents the coastline morphology from adjusting as it would on an undeveloped coastline. These questions apply broadly wherever increasing rates of sea-level rise or changing wave climates tend to increase rates of shoreline change. However, in this contribution we focus on cuspate coastlines, because they are characterized by locally high curvature and a broad range of coastline orientations (e.g., the coast of North Carolina in the U.S.), and are therefore particularly sensitive to changes in wave climate (Ashton and Murray, 2006a, 2006b, Slott et al., 2006). We present an analysis of shoreline change observations for each of the three cuspate coastline examples and use these observations, along with records of beach nourishment, analyses of wave data and model simulations, to determine whether the effects of wave climate change such as those suggested for largely-unaltered Capes Hatteras and Lookout by Moore et al., (2013) — are discernible in areas where changes in wave climate have been more subtle (e.g. Fishing Point, Maryland \& Virginia), where the coast has been modified by humans (e.g. Cape Fear, North Carolina) and where local geology may play a role in controlling coastline shape (Cape Canaveral, Florida).

We hypothesize that if changes in patterns of shoreline erosion and accretion (and therefore coastline shape) are not apparent in observations of Cape Fear, this may be because 
shoreline stabilization efforts have masked the response of the coastline to an increasingly

asymmetric wave climate. We also hypothesize that changes in wave climate may be too subtle to produce a detectable change in patterns of shoreline erosion and accretion in the vicinity of

Fishing Point, MD and that changes in wave climate along the eastern Florida coast may have altered the shape of Cape Canaveral over the last several decades.

\section{Background}

Recent changes in regional wave climate have been documented by Komar and Allan (2008), who analyzed 30 years of data from 3 buoys and found a trend of increasing summer season significant wave heights, especially for large waves (i.e., hurricane-generated), along a stretch of coast from New Jersey to South Carolina, with the magnitude of change increasing southward. The authors attribute this shift to increases in hurricane intensity observed by Emanuel (2005). Subsequent analyses have questioned the conclusion, based on these observations, that hurricane intensity was increasing during the 30 -year period, pointing out that the summer months (June - August) Komar and Allan separated in their analysis do not correspond directly to the tropical-storm season of June - November (Bromirski and Kossin, 2008). However, the subsequent analyses have not questioned either the existence of the increasing wave-height trends (whether all months or just the summer months are considered), or the point that waves with heights over $3 \mathrm{~m}$ during the summer months can be attributed to hurricanes (Komar and Allen, 2008). The hurricane-generated waves (heights > 3m) off the coast of Cape May, NJ have increased by an average of $0.01 \mathrm{~m} / \mathrm{yr}$ between the mid-1970s and 2005, while those off of Cape Hatteras, and Wilmington, $\mathrm{NC}$ increased in height by an average of $0.7 \mathrm{~m}$ and $1.8 \mathrm{~m}$ respectively over the same time period (Komar and Allan, 2008). McNamara et al. (2011) found that when summer season significant wave height increases off the coast of North Carolina, the wave 
climate - defined as the distribution of wave influences from different directions - becomes increasingly asymmetric, with a greater proportion of the influence on alongshore sediment flux coming from waves approaching from the east and northeast.

Sustained changes in the relative influence of waves coming from different directions will ultimately alter the shape of a coastline. Model simulations of a cuspate coastline using the Coastline Evolution Model (CEM; Ashton and Murray, 2006a) predict that increased patterns of storminess and associated wave climate alterations could result in greatly increased erosion rates in cuspate bays updrift of cape tips, and a strong tendency for accretion downdrift of cape tips (Slott et al., 2006). These alterations in shoreline change rates are superimposed on the background rates related to sea-level rise effects (e.g. Moore et al., 2010) and migration of largescale coastline features (e.g Ashton and Murray, 2006a).

To determine if the effects of wave climate change are discernible in observations, Moore et al. (2013) determined the difference between historic rates and recent rates of shoreline change along stretches of the North Carolina coast (including Capes Hatteras and Lookout). They compared these observations with model predictions for the response of a cuspate coastline to a wave climate specifically altered to reflect the increased summer significant wave-height trend identified by Komar and Allen (2008). Results suggest that the observed pattern of increasing erosion (accretion) along northern (southern) flanks of both capes is consistent with the modelpredicted change in coastline shape expected to arise from the changes in wave climate identified by Komar and Allan (2008) (Moore et al. 2013).

The two cape features examined by Moore et al. (2013) show a distinct geomorphic signature of wave climate change. Both are located near the zone of maximum summer significant wave-height increase identified by Komar and Allan (2008) and have been relatively unaltered by human activities. We can expect coastline response to wave climate change to be different or less 
detectable in areas where the change in wave climate is less pronounced or on developed coastlines affected by shoreline stabilization efforts.

Shoreline stabilization can dramatically change the way a cuspate coastline responds to a shift in wave climate, relative to what would occur without nourishment. Comparisons of numerical model experiments with and without nourishment (both involving the same waveclimate change scenario) suggest that the shoreline-change effects attributable solely to even an isolated zone of nourishment could exceed the magnitude of change expected from sea-level rise alone (Slott et al., 2010) — and that these anthropogenic effects can extend surprising distances up- and down-drift from the site of shoreline stabilization.

These long-range effects stem largely from the way shoreline angles are affected on an eroding stretch of coastline when one area is stabilized (Ells and Murray, 2011). Hypothetically, in the absence of wave-driven alongshore sediment transport, the stabilized area would protrude farther and farther seaward as the surrounding coastline recedes. However, gradients in alongshore sediment transport tend to produce a diffusive smoothing locally along sandy coastlines (e.g. Ashton and Murray, 2006a, b), which tends to prevent a stabilized section of coastline from protruding abruptly. As the stabilized section begins to protrude, the altered shoreline angles updrift and downdrift change the net sediment fluxes in ways that tend to keep the shoreline smooth. The pattern of shoreline change updrift and downdrift of a stabilized section depends on whether the stabilization is accomplished through hard structures (such as seawalls or groynes), or through beach nourishment, which adds new sediment into the nearshore system (Ells and Murray, 2011).

Averaged over time scales longer than that of the nourishment cycle, a long-term nourishment project must add sediment at the long-term rate required to prevent the stabilized area from eroding. As the stabilized area begins to protrude from the surrounding coastline, net sediment fluxes into the area from updrift tend to be decreased by the altered shoreline angles, 
while net downdrift fluxes out of the area tend to be increased. This tendency for an increased divergence of alongshore sediment flux means that nourishment rates must be higher than they would be if the stabilized area were not connected to the surrounding shoreline, reflecting the fact that the nourishment is partly stabilizing the surrounding coastline as well (Ells and Murray, 2011). With stabilization through beach nourishment, the effects on updrift and downdrift stretches of coastline are symmetric; even though the sand added during nourishment moves in the downdrift direction, the altered shoreline angles and curvature updrift of the stabilized area produce a convergence of sediment flux, and therefore deposition of sand from updrift, relative to what would occur in the absence of stabilization. How far updrift and downdrift the effects of the localized stabilization extend depend on the large-scale coastline morphology (as well as the length of time considered). In summary, where human and natural influences are coupled, the resulting system can exhibit complex responses to changes in forcing. By analyzing shoreline change and nourishment data for the developed Cape Fear region as a case study, we examine how localized, long-term beach nourishment interacts with changing climate forcing on cuspatecape coastline.

\section{Study Areas}

We examined three cuspate coastal landforms along the U.S. Mid-Atlantic coast (Figure 1); the highly-altered Cape Fear in North Carolina (NC) (Figure 1a), a northern location including portions of the Delmarva Peninsula near Fishing Point, considered by some to be a 'false cape' (e.g., Leatherman et al., 1982) (Figure 1b), and the region surrounding Cape Canaveral, Florida (FL) (Figure 1c). Each study area (encompassing the stretch of coast approximately 30km to the north and south of the cape tip) has experienced a unique combination of wave climate change and human alteration as outlined below.

Cape Fear, the southernmost of the three capes that characterize the coast of North Carolina, lies just south of Wilmington, NC (Figure 1a ). The northern flank of this cape, extending from 
Kure Beach to Fort Fisher, is considered part of the mainland, but features low-lying sandy shorelines and is backed by a water body (Cape Fear River), similar to a barrier island. The barrier islands along the southern flank of Cape Fear are primarily composed of channel-fill and are more tide-dominated (i.e. punctuated by a greater number of inlets) than counterparts to the north (Riggs et al., 1995). Relative sea level rise (RSLR) rates along the North Carolina coast have been between $3.0 \mathrm{~mm} / \mathrm{yr}$ and $3.3 \mathrm{~mm} / \mathrm{yr}$ throughout the twentieth century (Kemp et al., 2009). The coast adjacent to Cape Fear has been nourished repeatedly since the 1930s, particularly along Kure, Carolina, and Wrightsville Beaches (USACE, 1965; USACE, 1998; Valverde et al., 1999) (Figure 1a). This is in contrast to locations studied by Moore et al. (2013), in part, because Cape Hatteras and Cape Lookout lie within their own respective national seashores and are therefore managed by the National Park Service, remaining relatively unaffected by direct human influence (Valverde et al., 1999). Though Cape Fear differs from the other two NC capes in its degree of human manipulation, it exhibits similar morphology and is subject to the same high-angle wave climate and southerly net alongshore transport direction as Capes Hatteras and Lookout (Ashton and Murray, 2006a). The change in wave climate at Cape Fear is also likely to be similar to the change in wave climate at Capes Hatteras and Lookout because they are located in the same region, bracketed by buoys at which the increase in hurricane-generated wave heights has been identified by Komar and Allen (2008). For this reason, Cape Fear is an ideal location in which to assess the detectability of a geomorphic signature of wave climate change in the presence of human alteration to the coastline.

Approximately 200 kilometers north of Cape Hatteras, Fishing Point lies along the Delmarva Peninsula and includes coastline from southern Maryland (MD) and Virginia (VA) (Figure 1b). Barrier islands in the study area extend $\sim 30 \mathrm{~km}$ to the north and south of Fishing Point and include a portion of Assateague Island National Seashore (ASIS) in the north, and Wallops Island, Assawoman Island, Metompkin Island, Cedar Island and Parramore Island to the south. The latter 
two islands are located in the Virginia Coastal Reserve, which is Long Term Ecological Research site (VCR LTER). The islands of this region are mixed-energy barriers associated with a tidal range of approximately $1.24 \mathrm{~m}$, and a modern RSLR rate of approximately $4.3 \mathrm{~mm} / \mathrm{yr}$ (Hayes, 1979). The five barrier islands south of Fishing Point are retreating along their entire length, except for Parramore Island which exhibits alternating patterns of erosion and accretion at each end associated with changes in ebb channel location within the surrounding large ebb tidal deltas (Leatherman et al., 1982; Figure 1b). Direct human influence here is minimal (Valverde et al., 1999), with the exception of Wallops Island, which is home to NASA's Goddard Space Flight Center Wallops Flight Facility (WFF). The shoreline near the WFF has been the site of repeated shoreline stabilization efforts over the last century (NASA, 2010)—currently a seawall is being repaired and extended (WFF, 2011), and an associated nourishment project is scheduled for the near future (WFF, 2010). Because the strength of the trend in increasing wave height found by Komar and Allan (2008) decreases to the north, wave climate change along the Delmarva Peninsula has likely been less pronounced than it has along the North Carolina coastline (although shifts in wave-angle distribution could occur for other reasons).

Cape Canaveral (formerly Cape Kennedy) is approximately $660 \mathrm{~km}$ south of Cape Fear on the coast of east central Florida and lies on a peninsula, which hosts the Cape Canaveral Air Force Station. The tide range in this area is approximately $1 \mathrm{~m}$ (Nummedal et. al, 1977) and the local relative sea level rise rate is about $2.2 \mathrm{~mm} / \mathrm{yr}$ (Morton and Miller, 2005). In 1950, construction began on an artificial inlet (Port Canaveral) just south of the cape tip, which requires high rates of dredging to counter high rates of alongshore sediment transport (Work and Dean, 1990). The peninsula itself is composed of a series of northeast trending beach ridges that date to $\sim 4,000$ to 150 B.P. (Rink and Forest, 2005). Approximately $3 \mathrm{~km}$ north of the tip of Cape Canaveral is an area known as "False Cape," home to the Kennedy Space Center shuttle launch area (Figure 1c). Komar and Allan (2008) did not extend their analysis southward beyond the Charleston buoy 
(most directly offshore of Wilmington, NC), though the trend of greater increases in summer season significant wave height to the south (for the buoys analyzed by Komar and Allan (2008), suggests this region has also experienced an increase in hurricane-generated waves.

\section{Methods}

\section{Historical Shoreline Change Analysis}

To conduct a shoreline change analysis for the north and south flanks of Cape Fear, Fishing Point, and Cape Canaveral, we gathered available digital shoreline shapefiles (Table 1) and used them to quantify and compare shoreline change rates pre- and post- 1975 (which we refer to as historic and recent time periods, respectively). We selected 1975 as a breakpoint between historic and recent rate calculations to coincide with the beginning of the time period of wave observations analyzed by Komar and Allan (2008). Though the limited time period of wave observations prevents determination of when summer-season significant wave heights began to increase, analyzing two different periods allows us to determine how rates and patterns of shoreline change have shifted since wave observation began (and increases in wave height could be calculated). Available shorelines included 8 historic and 4 recent shorelines for Cape Fear (USGS, 2011; NOAA, 2012, NCDCM, 2011), 6 historic and 8 recent shorelines for the area surrounding Fishing Point (USGS, 2012; Oster, 2012; ASIS, 2012), and 11 historic shorelines and 11 recent shorelines for Cape Canaveral (USGS, 2012; NOAA, 2012; FF\&W, 2012). Though some of these shorelines offer only partial coverage of the study areas, we included all shorelines in shoreline change rate analyses to provide the most representative measure of shoreline change possible. (See Table 1 for a summary of shoreline metadata).

Following methods outlined by Moore et al. (2000), we calculated shoreline change rates

for each time period using the Digital Shoreline Analysis System (DSAS) for ArcGIS (Thieler et 
al., 2000). Because a 1975 shoreline was not available for the Cape Fear location, we shifted our breakpoint for Cape Fear to 1970 (consistent with the analysis of Moore et al., 2013). Prior to calculating shoreline change rates, we projected all shorelines into the State Plane Coordinate System and created an offshore baseline representing a visual average of all shorelines (i.e., representing the overall shape of the coast). Using DSAS, we then cast transects at $100 \mathrm{~m}$ intervals from the baseline to intersect shorelines at a roughly perpendicular orientation. The points where transects intersect the shorelines allow calculation of a linear regression rate (LRR) of shoreline change (with erosion rates having negative values and accretion rates having positive values) along each transect for each time period. Because we seek to quantify large-scale changes in coastline shape, we focus our analysis on stretches of coast dominated by long-term, rather than short-term (i.e., cape tip and inlet), processes. For this reason, we calculated rates of shoreline change along all stretches of coast that are at least $2 \mathrm{~km}$ away from cape tips and beyond the zone of inlet influence, which we qualitatively approximate as stretches of coastline where all shorelines (across the time period of observation) on either side of an inlet are roughly parallel to one another.

For some time periods and stretches of coast only two shorelines were available, preventing calculation of LRRs (which requires a minimum of three shorelines) along the entire stretch of coast (i.e., 100\% of the coastline analyzed). In such instances, we calculated an end point rate (EPR) instead (Table 2; see Supporting Information Section I for more detail). After calculating shoreline change rates, we applied a Gaussian filter (1km for Cape Fear and Cape Canaveral, and $600 \mathrm{~m}$ for Fishing Point) to each set of rates to discern large-scale trends. Because transects (and therefore shoreline change rates) within a window equal to one half of the filter length are lost at the end of each dataset and adjacent to gaps within a data set (e.g. between islands or on either side of an inlet-influenced shoreline), we chose a filter length that was as short as possible (to minimize data loss but long enough to highlight general trends in shoreline change 
rates across the study area. We applied the shorter filter length in the Fishing Point study area to reduce data loss that would occur with the longer filter length across the short, discrete islands that make up this stretch of coast.

Depending on the original data source, each shoreline has a positional uncertainty associated with errors in georeferencing, digitization, t-sheet surveys, wet/dry line interpretation, pixel size, lidar position and/or shoreline proxy offsets (e.g. Moore et al., 2000, Morton and Miller, 2005; Moore et al., 2006, Limber et al., 2007, Fletcher et al., 2012). For some shorelines positional uncertainty estimates were provided in associated metadata. When uncertainty estimates were not provided, we estimated the maximum positional uncertainty based on shoreline type using an established value from the literature, or we summed in quadrature (following Morton and Miller (2005) and Fletcher et al. (2012)) estimates for all applicable errors based on values available in the literature or values derived from our own analyses (as in the case of most shorelines derived from aerial imagery for Cape Canaveral) (Tables 1 and 3). We then used DSAS to calculate an uncertainty estimate at each transect for each shoreline change rate (historical and recent) within a 90\% confidence interval (as in Morton and Miller, 2005). Because each filtered LRR or EPR shoreline change rate is derived from adjacent rates, actual uncertainty estimates associated with the filtered rates presented in Figures 10-12 are lower than uncertainty estimates on the raw rates. Thus, following Fletcher et al. (2012) we determined the uncertainty estimate for each filtered rate according to:

$$
U_{a v g}=\frac{\sqrt{\sum_{i=1}^{n} U_{i}^{2}}}{n}
$$

where $U$ is the uncertainty and $n$ is the number of transects used to determine the filtered rate. For Cape Fear and Cape Canaveral, $\mathrm{n}=10$ (transects at 100m spacing, $1 \mathrm{~km}$ filter) and, for Fishing Point $\mathrm{n}=6$ (transects at $100 \mathrm{~m}$ spacing, $600 \mathrm{~m}$ filter). Minimum, maximum and average $\mathrm{U}_{\text {avg }}$ for filtered rates are reported in Table 4 . We also calculated and reported $U_{\text {avg }}$ for the cape-flank- 
average filtered shoreline change rates presented for the north and south flank of each cape (Figures 10-12). Though it provides a more representative estimate of uncertainty than simply averaging uncertainty values, summing in quadrature involves the assumption that all transects are independent. It is also highly influenced by the few very high uncertainty estimates in raw and filtered shoreline change rates (e.g., Table 4). The former will tend to lead to underestimation of uncertainty and the latter will tend to lead to overestimation.

To determine shifts in patterns of coastline change, we calculated the difference in shoreline change rates (which we call shoreline change rate differences-SCRDs) between historic and recent time periods by subtracting the historic rates of shoreline change from the recent rates of shoreline change.

Positive (negative) SCRD values indicate that the coastline is becoming increasingly accretional or less erosional (increasingly erosional or less accretional) since the observed onset of an increasingly asymmetric wave climate. If the rate of shoreline advance/retreat is the same from the historic to the recent, then the SCRD will be zero. We used $U_{\text {avg }}$ for the average shoreline change rates by flank to calculate $U_{\text {avg }}$ for the average shoreline change rate differences (SCRDs) by flank (Figures 10-12).

\section{Beach Nourishment Data}

We downloaded data regarding the timing and volume of beach nourishment along both flanks of Cape Fear from the Program for the Study of Developed Shorelines (PSDS, 2012). Between 1939 and 2010, approximately 70\% of the Cape Fear study area was nourished at some point. Data from PSDS include nourishment volumes and the length of coastline along which nourishment sand was distributed for individual communities. We divided the episodes of nourishment into five-year bins to more easily discern general trends in nourishment volume through time (Figure 2). We then determined the cumulative nourishment sand volume along both 
flanks of Cape Fear and calculated regression rates for each of three time periods having different rates of sand emplacement.

To discern spatial patterns in nourishment activity we separated the nourishment episodes by community. We then selected a representative community length to calculate a normalized nourishment volume per meter of shoreline per community. We chose the community length by determining the greatest alongshore length of a single nourishment episode as given for each community in the PSDS (2012) data. We did not analyze nourishment volumes on the southern flank of Cape Fear because nourishment activities there began only after the onset of the observed changes in wave climate.

\section{Wave Climate Change Analysis}

Komar and Allan (2008) analyzed data from wave buoys, yet their analysis did not include areas in the vicinity of Fishing Point and Cape Canaveral, presumably because wave buoys are not available in these locations. To analyze both for an increase in wave height and direction in the vicinity of Fishing Point and Cape Canaveral, we gathered data from 41 U.S. Army Corps of Engineers Wave Information Study (WIS) stations (22 from FP and 19 from Cape Canaveral).

(WIS data can be downloaded from wis.usace.army.mil). Using measured wind speed and directional data, WIS stations provide hindcasts of significant wave height at 3-hour intervals from 1980 to 1999. Following the analysis of buoy data by Komar and Allan (2008), for each station we calculated a linear regression for both summer season (July-Sept) and hurricane season (June - Nov.) significant wave height. We then separated waves greater than $3 \mathrm{~m}$ in height, identified as hurricane-generated waves when occurring in the summer months (Komar and Allan, 2008), and determined the rate of wave height increase (Figures 3 and 4). All trends are significant at the $95 \%$ confidence level using the Wilcoxon rank-sum test. 
To assess the directional effects of increases in summer (or hurricane) season significant wave heights on wave climate, we examined changes in wave approach angle. We identified a general shoreline trend $\left(28^{\circ}\right.$ for Fishing Point and $340^{\circ}$ for Cape Canaveral), which was used to determine the relative wave approach angle. We calculated probability distribution functions (PDFs; representing the relative influence on alongshore sediment flux from different offshore wave-approach directions) for the overall annual wave climate, the summer months (July - Sept.), the non-summer months (Oct. - June) (Figures 5 and 6), hurricane season (June - Nov.) and nonhurricane season (Dec. - May). (See Section II of Supporting Information for analyses of data from all WIS stations used in this study.)

\section{Coastline Evolution Model Simulations}

We used the Coastline Evolution Model (CEM) (Ashton and Murray, 2006a) to predict how historical nourishment patterns, such as those occurring in the vicinity of Cape Fear, would likely alter shoreline change rates in the presence and absence of changes in wave climate. CEM uses a probability distribution function (PDF) to select a daily offshore wave direction and angle (relative to a general alongshore domain), calculates wave shoaling and refraction over assumed shore-parallel contours until depth-limited breaking occurs, and then uses the CERC equation to calculate alongshore sediment transport (Ashton and Murray, 2006a). The wave-climate PDF can be based on observed or hindcast wave data; it can be constructed to reproduce the relative influence on alongshore sediment transport from waves within specified wave-angle bins. Although the same set of waves occurring in different sequences produce different cross-shore profile shapes over timescales of months (Southgate, 1995), previous experiments with CEM (unpublished) have shown that when addressing large-scale, long-term coastline plan-view morphodynamics, the sequencing of waves (e.g. temporal correlation of wave-angle directions to represent storms vs. random selection from within the PDF) do not affect model results. Within 
the model, perturbations in coastline shape that extend offshore can shadow adjacent coastline segments from incoming wave energy, altering the net rates of alongshore sediment transport (Figure 7). Gradients in alongshore sediment flux determine shoreline movement. Erosion and accretion are assumed to extend along the equilibrium shoreface profile and the profile shape remains constant. Starting with a simplified, straight, sandy coastline and using a PDF based loosely on wave hindcast statistics from WIS station 509, we generated a cuspate Carolina-like coastline for use as an initial condition (Slott et al., 2010; Ells and Murray, 2012). This initialcondition coastline exhibits the main morphological characteristics of the Carolina Capes, but is not intended to be a detailed simulation of that particular coastline. The modeling focuses on alongshore sediment transport processes, intentionally omitting many processes and boundary conditions believed to play a secondary role in large-scale sandy-coastline evolution. Our goal is to generate broadly applicable insights rather than to investigate Cape Fear specifically, and in addition model simplifications combined with inevitable limitations of wave-climate data would prevent any attempt to use the observed coastline as an initial condition (without having the interesting climate-change signals swamped by model spin-up adjustments of the morphology to the input wave forcing). For model runs including wave climate change, we initiated a linear increase in the probability of waves approaching from the east and northeast starting in 1970 (Figure 8).

To simulate beach nourishment we chose two locations (along the northern flank of the modeled cuspate feature chosen to represent Cape Fear) that approximate the alongshore position of Wrightsville Beach (“Town 1") and Carolina Beach (“Town 2") relative to the cape tip, because these two communities have a history of nourishing in large quantities (Figure 1 and Figure 9). In each simulation, at each time step, CEM calculated the volume of sand required to stabilize the nourished stretches of coastline (to maintain the shoreline position that existed at the time nourishment began), recorded that volume, and instantaneously added that volume of sand to 
the shoreline (implicitly spread across the shoreface) to maintain the initial shoreline position. (This nourishment algorithm is only applied within the coastline segments designated as 'stabilized', although these local actions also tend to stabilize surrounding stretches of coastline through their effects on nearby shoreline orientations and therefore patterns of alongshore sediment transport.) We ran two initial simulations, one without and one with wave climate change. In these simulations, we began nourishment immediately and constrained the extent of nourishment within each ‘town' to limited alongshore zones (dark grey bars in Figure 9). To explore the effect of observed increases in nourishment rate in neighboring communities with time (e.g. Figure Eight Island and Kure Beach), we ran a third simulation in which nourishment was constrained for the first 45 years to the limited alongshore zones but then expanded in modelyear 1985 (to the areas represented by light grey bars in Figure 9).

\section{Results}

\section{Shoreline Change}

During the historical time period (pre-1970), shoreline change rates for Cape Fear are largely erosional (Figure 10a). The southern flank has a fairly uniform erosion rate of approximately -0.5 to $-1.5 \mathrm{~m} / \mathrm{yr}$ and though erosion is also widespread on the northern flank, most locations are only slightly erosional ( 0 to $-0.5 \mathrm{~m} / \mathrm{yr}$ ). The few erosion hotspots on the northern flank appear to be associated with historical inlet migration. In contrast, recent rates of shoreline change along the southern flank are close to zero or accretional, and in some areas rates are greater than $1.5 \mathrm{~m} / \mathrm{yr}$ (Figure 10b). The northern flank is also accretional in the recent time period, but a localized zone of high erosion rates occurs south of the Masonboro Inlet Jetty. The shoreline change rate difference (SCRD) indicates that much of the coastline to the north and to the south of Cape Fear has become more accretional since 1970 (Figure 10c). The recent erosion hotspot on the northern flank just south of Masonboro Inlet appears as an isolated location of highly negative 
SCRD values, indicating that this erosional trend has developed since 1970. Whereas a more accretional southern flank is consistent with an increasingly asymmetric cape (Moore et al., 2013; Slott et al., 2006), the recent accretional trend on the northern flank appears inconsistent with the hypothesized adjustment to a changing wave climate (in the absence of shoreline stabilization).

Farther to the north in the area surrounding Fishing Point, a different pattern of shoreline change emerges (Figure 11). For the historic time period, the northern flank can be divided into a southern zone of moderate accretion (up to $>2.5 \mathrm{~m} / \mathrm{yr}$ ) a mid-zone of moderate erosion (up to -1.5 $\mathrm{m} / \mathrm{yr}$ ) and a northern zone of little change (0.5 to $-0.5 \mathrm{~m} / \mathrm{yr}$ ) (Figure 11a). Prior to 1975 , the area south of Fishing Point was highly erosional (-1.9 to $-5 \mathrm{~m} / \mathrm{yr}$ ) except for Parramore Island at the southern end, which was moderately accretional (1.5 to $2.5 \mathrm{~m} / \mathrm{yr})$. Since 1975 , the entire study area, except for a few short stretches (all less than $1.5 \mathrm{~km}$ in length), has been erosional, with the greatest rates of erosion (up to $-12.5 \mathrm{~m} / \mathrm{yr}$ ) occurring at the southern end of the south flank near Parramore Island (Figure 11b). This large increase in the rate of erosion across the study area is highlighted by negative SCRD values along both the northern and southern flanks (Figure 11c). A prominent and well-documented exception to this is Wallops Island, where the historically high rate of more than $-2.5 \mathrm{~m} / \mathrm{yr}$ has been reduced to values near zero $(-0.5-0.5 \mathrm{~m} / \mathrm{yr})$ in the recent past as a result of shoreline stabilization efforts designed to protect the NASA Wallops Flight Facility (NASA, 2010). Because the barrier islands along the southern portion of this study area are limited in spatial extent and because inlets have heavily influenced much of the southern portion of the study area over time, there are significant data gaps along the southern flank. As a result, rates are limited in spatial coverage and may not necessarily be representative of overall coastal change in the region.

In the historic time period (prior to 1970), shoreline change rates for Cape Canaveral are generally low (between 1.5 and $-0.5 \mathrm{~m} / \mathrm{yr}$ ) except near the cape tip itself (Figure12a). High rates of accretion near the cape tip on the southern flank gradually decrease southward to near zero 
$(-0.5 \mathrm{~m} / \mathrm{yr})$, whereas the high erosion rates near the cape tip on the northern flank $(-1.5$ to -2.5

$\mathrm{m} / \mathrm{yr}$ ) rapidly decrease northward becoming near zero (0 to $-0.5 \mathrm{~m} / \mathrm{yr})$ and then moderately accretional (0.5 to $2.5 \mathrm{~m} / \mathrm{yr})$. (Note: in the northernmost extent of the study area, only two shorelines were available for each time period (1875 and 1924 and 1999 and 2004) and therefore shoreline change rates along this stretch are EPRs rather than LRRs.) Patterns of recent shoreline change along the southern flank of Cape Canaveral are similar to the historic patterns - rates are highly accretional immediately south of the cape and transition to roughly zero $( \pm 0.5 \mathrm{~m} / \mathrm{yr})$ southward (Figure 12b). Although the flank-averaged rates of change for the northern flank are similar between the two time periods, shoreline change rates are more variable alongshore since 1970 with greater extremes in rates of erosion and accretion (e.g., -2.5 to $>2.5 \mathrm{~m} / \mathrm{yr}$ ). Immediately north of the cape tip SCRDs indicate the area is increasingly less erosional compared to the historical time period, whereas a short stretch immediately south of False Cape is more erosional (by $-1.5 \mathrm{~m} / \mathrm{yr}$ to $-2.5 \mathrm{~m} / \mathrm{yr}$ ) (Figure $12 \mathrm{c}$ ). Another zone of slightly enhanced accretion occurs along False Cape itself whereas a zone of enhanced erosion (-0.5 m/yr to $-2.5 \mathrm{~m} / \mathrm{yr})$ occurs immediately to the north. These observations are in agreement with the analyses of Absalonsen and Dean (2010).

\section{Wave Climate}

Our wave analysis for Fishing Point is consistent with the range of values reported to the north and south by Komar and Allan (2008) and suggests that increases in summer season (July Sept.) and hurricane generated (summer waves $>3 \mathrm{~m}$ ) wave height within the vicinity of Fishing Point (WIS Stations 163, 165-178, 180-188) were small (between 0.015 and $0.021 \mathrm{~m} / \mathrm{yr}$ ) (Figure 3). Our analysis for Cape Canaveral (WIS Stations 416-418, 430-440, 518-521) suggests an average increase of $0.009 \mathrm{~m} / \mathrm{yr}$ in summer season significant wave height, and a greater average increase of $0.050 \mathrm{~m} / \mathrm{yr}$ in hurricane-generated wave height (Figure 4). When we extended our 
analysis of stations in the vicinity of Cape Canaveral to include the entire hurricane season (June - Nov.), results were similar - indicating an average increase of $0.008 \mathrm{~m} / \mathrm{yr}$ in overall hurricane season waves, and an average increase of $0.05 \mathrm{~m} / \mathrm{yr}$ in hurricane-generated waves.

We examined PDFs representing the relative influences on alongshore sediment flux from different offshore wave approach angles for the Fishing Point and Cape Canaveral wave climate data (Figures 5 and 6) to assess the effect of increases in hurricane-generated-wave height on the relative influence of waves on alongshore transport. The analysis reveals an annually bimodal wave climate at Fishing Point, with a greater contribution from waves approaching from the left (northeasterly) (Figure 5a). During non-summer months, the wave climate is similar to the annual wave climate (Figure 5b). During the summer months the wave climate appears more strongly bimodal in comparison to the annual wave climate with more waves approaching from high angles and the right (south) (Figure 5c). Hurricane-generated waves (those $>3 \mathrm{~m}$ ) approach from predominantly high angles, with a greater proportion from the east and northeast (left) than the south (right) (Figure 5d). Near Cape Canaveral, the wave climate appears low-angle and slightly asymmetric, with a greater influence of waves coming from the left (north/northeast) relative to the general orientation of the shoreline (Figure 6a). The PDF of wave direction for non-summer months is similar to the annual analysis, displaying only a small change in the proportion of waves approaching from the left at high angles (Figure 6b). Conversely, the PDF of wave direction for summer months suggests a slight increase in high-angle waves from the left (north/northeast) (Figure 6c) while the hurricane-generated waves approach shore from predominantly low-angles with a slight asymmetry to the left (north/northeast) (Figure 6d).

\section{Nourishment Observations and Modeling}

We identified three distinct trends in the binned beach nourishment data (Figure 2). From $\sim 1935$ to 1960 , the rate of nourishment was low $\left(32,000 \mathrm{~m}^{3} / \mathrm{yr}\right)$ because relatively few 
nourishment episodes took place during this time period. After 1960, the rate of beach nourishment in the vicinity of Cape Fear increased by an order of magnitude (to $415,000 \mathrm{~m}^{3} / \mathrm{yr}$ ) and nearly doubled after 1980 (to 690,000 m³/yr). Along Wrightsville Beach and Carolina Beach, nourishment has taken place since the 1930s, and the 1950s, respectively, with major episodes of nourishment continuing to present day. The spatial distribution of nourishment through time indicates that nourishment along Wrightsville Beach and Carolina Beach accounts for over 70\% of the total volume of sand emplaced along the northern flank of the cape $(34 \%$ and $37 \%$, respectively). Because it has the longest history of human alteration of the three study areas, we focused model simulations on the northern flank of Cape Fear to test our hypothesis that the absence of a pattern of shoreline change rates consistent with Moore et al. (2013) suggests that beach nourishment is compensating for - and therefore masking - the effects of changing wave climate along Cape Fear.

As discussed above in the methods section, we conducted model simulations without and with a changing wave climate (i.e., steady vs. increasingly asymmetric wave climate) as well as with and without spatial expansion of nourishment. For model simulations in which the wave climate was steady, the resulting trend in cumulative beach nourishment volume is roughly linear (dashed black line, Figure 13), implying a temporally consistent tendency for the shoreline to retreat, which is counteracted by a relatively consistent input of sand through time. Through the updrift and downdrift effects of shoreline stabilization, the localized nourishment in these model runs effectively prevents the erosion of the whole flank of the cape updrift of the cape tip (the 'northern' flank) — erosion that would otherwise occur as the cape features migrate downdrift (e.g. Ashton and Murray, 2006a). However, for model simulations in which the wave climate becomes increasingly asymmetric (Figure 8), the rate at which sand needs to be added to maintain the initial shoreline position increases throughout the simulation (dotted black lines, Figure 13). The increase in the rate of sand input occurs shortly after the initiation of wave climate change in the 
model (1970), in response to the tendency for erosion rates along the north flank to increase under the increasingly asymmetric wave climate. The black dotted line with open circles (Figure 13) indicates the cumulative volume of sand input that is required to stabilize the shoreline when we include the 1985 expansion of nourishment zones in the wave climate change simulation. For comparison, we also show in Figure 13 (solid black line), the observed trend in cumulative nourishment volume for both towns combined (from Figure 8).

From 1940-1960, the rate of sand input in all three simulations is considerably larger than the actual rate of nourishment (Figure 13, dashed black line vs. solid black line). Around 1965 there is a rapid increase in observed cumulative nourishment volume and the difference between observations and model simulations is reduced. Starting around 1985, the slope of the observed trend in cumulative nourishment volume and the slope of the trend in model-generated cumulative nourishment volume for both simulations including wave climate change (Figure 13, dotted black line and dotted black line with circles) are similar, indicating that nourishment rates in the simulations approximately equal those observed during this time period. The match between observed and model-generated volumes is considerably less good for the simulation in which wave climate change is not included (Figure 13, continuation of the dashed black line).

Throughout the three simulations we tracked model- generated cumulative nourishment volumes for each town for comparison with observed nourishment volumes for each town (Figure 13, blue and green lines). Modeled nourishment volumes for Town 1 (representing Wrightsville Beach) — with and without wave climate change (dotted and dashed blue lines, respectively) — are initially (1940 - 1980) larger than observed volumes (solid blue line). Beginning around 1980 there is a large increase in the observed cumulative volume and the trends switch such that the observed cumulative volume becomes greater than model- generated cumulative volume. In the case of Town 2 (which approximates Carolina Beach,) model- generated cumulative nourishment volume is higher than the observed cumulative volume throughout time (except after 1980 in the 
simulation without wave climate change) (Figure 13, green lines). Thus, it is the combination of a slight-under prediction in the vicinity of 'Town 1' and a slight over-prediction since 1980 in the vicinity of 'Town 2' that results in an overall rate of model- generated nourishment volume that matches the observations. The fact that the total combined rate of nourishment from both towns together matches the observations better than either town individually-combined with the result that the combined nourishment rate does not depend significantly in the model on whether the nourished areas are expanded in 1985 or not (solid line and circles in Figure 13 nearly coincide)—supports the conclusion that the localized nourishments, in concert, effectively prevent erosion along the whole 'northern' flank of the cape, through the updrift and downdrift effects associated with alongshore sediment transport.

\section{Discussion}

Moore et al. (2013) examined two prominent cape features and found significant changes in coastline evolution that are consistent with observed changes in Atlantic Ocean wave climate. Here we have extended that analysis to assess the signature of wave climate change in the evolution of cuspate coastlines under different conditions.

\section{Limitations}

The extent and accuracy of the shoreline change analysis is limited by the number of shorelines available. Increasing the number of shorelines lends increased accuracy to analysis (Dolan et al., 1991), but not all shorelines extend along the entire study area. While use of LRRs to compute shoreline change is widely accepted, it is subject to the influence of outliers. Assumptions of a linear trend in shoreline change may not reflect trend reversals or capture cyclical changes in shoreline position (Dolan et al., 1991). However, including as many 
shorelines as possible over the longest time span available reduces these biases (Dolan et al., 1991)

Moore et al. (2013) defined their breakpoint, between recent and historic shoreline change analyses, at 1975 because the observations of wave height began in 1975 (Komar and Allen, 2008). Because a 1975 shoreline is not available for Cape Fear, we instead used a breakpoint of 1970 for this study area. If wave height began increasing prior to 1975 , the use of an earlier breakpoint would increase the contrast between the two time periods and therefore enhance the signature of a geomorphic response. If wave height began increasing closer to 1975, then our inclusion of 1970 in recent shoreline change calculations reduces the difference between the historic and recent time periods, likely decreasing the strength of any geomorphic signature. However, across such temporal-spatial scales (of years to decades and tens of kilometers) a breakpoint in 1970 instead of 1975 should have negligible impact on our results.

The use of buoy data for wave climate analysis does have several shortcomings.

Instrumentation changes, gaps in measurements and changes in measurement calculations can introduce error into data, making it appear that increases in wave heights are larger than when these sources of error are corrected for (Gemmrich et al., 2011). In addition, WIS station (509) used as a guide for choosing wave climate parameters that produce a Carolina-like coast—is located at a position where water depth is considerably deeper than the base of the shoreface. After daily wave angles are selected from the PDFs generated from WIS data, CEM refracts these waves across shore-parallel bathymetric contours, so that wave data from the base of the shoreface would be more appropriate. However, wave data collected at a location near the base of the shoreface, and therefore closer to the shoreline, would not (because of wave-shadowing effects) receive a distribution of waves that is representative of the wave climate affecting the coastline more broadly. Thus, we use WIS station 509 as a rough basis for our wave climate parameters, despite the shortcomings. Since our goal was to use model simulations to explore the 
generic large-scale response of a cuspate coastline to repeated nourishment episodes in the absence and presence of wave climate change (rather than a site-specific investigation of Cape Fear), the potential inaccuracies inherent in buoy records (Gemmrich et al., 2011), and those introduced by the assumption of shore-parallel contours, are likely inconsequential to the main results of our analysis.

Nourishment data gathered from PSDS (2012) was grouped by community and into 5-year bins, somewhat reducing the temporal resolution of the data. To represent nourishment in model simulations, we generalized the extent of nourishment by selecting two zones within which nourishment would take place. Because over $70 \%$ of the volume of sand emplaced on the northern flank of Cape Fear was emplaced within these zones, we do not expect this generalization to affect our results in a meaningful way.

\section{Coastline Response to Wave Climate Change}

Moore et al. (2013) found that Cape Hatteras and Cape Lookout have become increasingly asymmetric since 1975 in response to an increasingly erosional (accretional) pattern of shoreline change on the northern (southern) flanks of each cape. To link their observations to a change in wave climate, Moore et al. (2013) used CEM to confirm that the increasingly asymmetric shape of these cape features could result from an increasingly asymmetric high-angle wave climate reflective of the Komar and Allan (2008) observations. In contrast to Capes Hatteras and Lookout, the SCRD values for Cape Fear are generally accretional on both flanks (Figure13). While an increasingly accretional southern flank is consistent with an increasingly asymmetric cape, the more accretional signal along the northern flank (with the exception of the more erosional area south of Masonboro Inlet jetty) initially appears inconsistent with the findings of Moore et al. (2013). 
CEM simulations for the evolution of a nourished, cuspate coastline match observations of shoreline change and beach nourishment trends best when a change in wave climate (consistent with observations; Komar and Allan, 2008) is included (Figure 13). The simulation results provide support for our hypothesis that beach nourishment activities have masked an erosional signal that may have been otherwise visible in recent shoreline change observations along the northern flank of Cape Fear. To stabilize the shoreline, simulations without a change in wave climate require a steady rate of nourishment to prevent local erosion, which is inconsistent with observations (Figure 13). In contrast, simulations including an increasingly asymmetric wave climate result in nourishment rates that increase monotonically, consistent with observations of cumulative beach nourishment volume emplaced. This suggests that increasing amounts of sand are needed per nourishment episode to stabilize a stretch of coastline that is increasingly out of equilibrium with changing conditions.

From 1940-1960 (an era without a record of increasing summer season significant wave heights) in all simulations, observed nourishment volumes are lower than the modeled volumes needed to maintain a stable shoreline (Figure 13) which suggests the coast was eroding during that time and that nourishment was not undertaken at a rate sufficient to counter landward shoreline motion. This could be due in part to a smaller coastal population and lack of concern over erosion, or to limited technology available to extract and emplace sand resources at a rate sufficient to counter erosion. From 1960 to 1985 observed rates of nourishment dramatically increase until the cumulative volume approaches model-generated volumes. This may represent a shift in population, decision-making and/or availability of technology, which led to emplacement of sand via nourishment at a rate sufficient to make up for shoreline erosion in the previous decades. After approximately 1985 - the period in which the full spatial extent of nourishment for each town was allowed (in the third simulation) to be consistent with the observed timing and 
location of nourishment—observed and model-generated nourishment volumes are closely aligned both in magnitude and trend (Figure 13).

Although shoreline change observations alone do not reflect the geomorphic signature of an increasingly asymmetric wave climate, model-generated and observed increases in the rate at which sand was emplaced through time suggest that the coast was becoming increasingly erosional. With the exception of one location on the north flank of Cape Fear where nourishment has not taken place (i.e. south of Masonboro Inlet, which is downdrift of an inlet where jetties partially block alongshore transport) nourishment artificially stabilized the whole coastline segment updrift of the cape (reflected in shoreline change patterns) thereby compensating for coastline changes that would have otherwise occurred. In this case, coastline response to changing wave climate appears to be discernible via changes in the volume of sand emplaced via beach nourishment activities through time. These potential insights extend beyond the context of cuspate capes subject to changing wave climates. On any sandy, wave-dominated coastline where erosion rates are increased (by either increased rates of sea-level rise or by changing storm/wave climates), even localized stabilization, through its updrift and downdrift effects, will tend to at least partially mask coastline response to climate change-converting the response into one that occurs chiefly in the human component of the system.

Though the increase in summer season significant wave height has been smaller in the vicinity of Fishing Point than elsewhere, based on our analysis of WIS data, an increase in hurricane-generated waves would likely result in a slight increase in the influence of waves coming from the east and northeast (Figure 5d). If this shift were sufficient to alter patterns of erosion and accretion we would expect it to produce a pattern of increasing erosion/less accretion on the northern flank and decreased rates of erosion/more accretion on the southern flank proximal to the cape, in a pattern similar to that observed for the Carolina capes. This is consistent with the pattern of SCRD values on the northern flank as well as with the increasing rates of 
southward migration of Fishing Point in recent decades (Leatherman et al., 1982). Although the high rates of shoreline change locally occurring on Parramore Island in the southern portion of the study area are inconsistent with the pattern of shoreline change we might expect in response to changing wave climate, this stretch of coast is heavily influenced by inlets and the rotation of this island's shoreline around a central axis (i.e., alternating patterns of erosion and accretion at the north and south ends) (Leatherman et al., 1982), the effects of which would likely overwhelm the subtlety of a long-term signal of wave climate change such as we have sought to detect. In addition, Parramore Island may be experiencing increased erosion rates in response to southward extension of the cape feature through time which results in a southward shift of the wave-shadow zone (and thus locally high, negative alongshore sediment transport gradients at the down-drift edge of the wave-shadow zone). Given the more subtle nature of changes in wave climate in this area, factors other than changing wave climate may also explain the enhanced erosion rates along the northern flank in recent decades. For example, Fishing Point is located in a zone of accelerating sea level rise, related to weakening of ocean circulation patterns in the Atlantic (Sallenger et al., 2012; Ezer et al., 2013) and because this is a region of low-lying islands, negative feedbacks related to overwash frequency and dune-grass species composition may be contributing to widespread shoreline retreat (Wolner et al., 2013).

The changes in wave climate in the vicinity of Cape Canaveral differ from those observed near Cape Fear and Fishing Point. Directional wave analysis suggests that the wave climate (overall, summer months, and hurricane-generated) is dominated by low-angle waves. However, consistent with analyses by Absalonsen and Dean (2010), our shoreline change analysis does not reveal shoreline retreat at the False Cape protrusion, but rather shoreline stability and possible advancement, despite the low-angle wave climate. Perhaps more interesting, is the occurrence of Cape Canaveral in the presence of a low-angle wave climate. This appears contrary to findings by Ashton et al. (2001) who suggest that cape features on sandy coastlines originate from a high- 
angle wave climate. We offer two hypotheses to explain this apparent discrepancy: (1) It is possible that Cape Canaveral and False Cape persist in their current configuration because of underlying geologic control, such as the presence of the Anastasia Formation in the Cape Canaveral vicinity, which may impede 'natural' barrier island formation farther south (Finkl et al., 2008; Lovejoy, 1983). For example, if locally 'hard' geology tended to pin the shoreline location (thereby locally reducing erosion, relative to areas updrift and downdrift) a protruding portion of the shoreline would develop, with a smooth updrift shape analogous to that updrift of a groin or jetty_-potentially explaining the presence of False Cape and the shape of the shoreline updrift. The orientation of the shoreline just downdrift of the protrusion, then, would tend to become increasingly oblique relative to the regional coastline trend. The relative angles between the approaching waves and the reoriented coastline could ultimately tip toward high-angle dominance, possibly producing the growth of a subsidiary cape on the downdrift flank of the protrusion - potentially explaining the formation of Cape Canaveral under what is a low-angle wave climate with respect to the overall coastline trend. (2) The effects of refraction of the assailing wave field by cape-associated shoals may alter the pattern of alongshore sediment transport (AST), setting up AST gradients conducive to a pattern of perturbation growth (Kline et al., in review). Both of these hypotheses offer explanations for shoreline change rates, and SCRD values to differ from what might be expected under an increasingly low-angle wave climate. However, further exploration of this deviation is beyond the scope of this manuscript.

Overall, our analysis suggests that coastline response to a changing wave climate, as well as the detectability of coastline response, is dependent on numerous factors including the effects of human intervention and geology. In some regions (e.g. Cape Fear, NC) coastline response to a changing wave climate may not be observable directly from shoreline change rates, but might instead be evident in records of shoreline stabilization efforts. Cape Canaveral and Fishing Point appear to be subject to changes in wave climate, but local factors (i.e. less-pronounced changes in 
wave climate, underlying geology, or the presence of complex nearshore bathymetry) may be suppressing coastline response to these changes.

If changes in mid-Atlantic wave climate continue, new and continued shifts in alongshore patterns of erosion and accretion may occur and extend beyond cuspate features, resulting in regional changes in the location of erosional 'hot spots.' This would likely alter the spatial distribution of beach nourishment activities, potentially leading to new areas of nourishment and increasing competition for available nourishment sand (e.g. McNamara et al., 2011). If predicted increases in hurricane activity (e.g., Emanuel, 2013) and sea level rise (IPCC,2014) are realized, wave climate change, coastal erosion, and the consequent coupling of the human and coastline systems may be enhanced along sandy coastlines in the future.

\section{Conclusions}

Using a combination of shoreline change analysis, nourishment observations, wave analysis and model simulations we have provided support for our hypothesis that the effect of changes in wave climate may be discernible in changing patterns of shoreline stabilization along developed cuspate coastlines (e.g., Cape Fear, NC). Along some cuspate coastlines (e.g., Fishing Point, MD/VA; Cape Canaveral, FL) wave climate may be changing, but local variations in a range of factors appear to prevent us (at this time) from detecting any specific change in shoreline behavior that we can reliably attribute to shifts in wave climate. As climate change leads to potentially more frequent and/or more intense hurricanes in the future, we can expect changes in wave climate to continue, resulting in more dramatic shifts in alongshore sediment transport gradients, thereby extending the effects of wave climate change to sandy coastlines in general. Changes to wave climates, in conjunction with SLR, have the potential to lead to increased coastal erosion, and will influence future human-coastline interaction. How humans respond to these changes will also significantly impact coastline shape. 


\section{Acknowledgements}

We gratefully acknowledge funding for this work provided by a grant from the Geomorphology and Land Use Dynamics Program of the National Science Foundation (\#EAR 1053141) and the Martin Fund in Geological Sciences at the University of North Carolina Chapel Hill. We thank Tamlin Pavelsky and Tony Rodriguez for feedback on earlier versions of this manuscript. We thank Editor Lane and two anonymous reviewers for their thoughtful comments and suggestions, which improved the final version.

\section{References}

Absalonsen, L., and Dean, R. G. 2010. Characteristics of the Shoreline Change Along the Sandy Beaches of the State of Florida: An Atlas, No. FLSGP-M-10-001, pp. 1-304. National Sea Grant Library.

Adams P. N., Inman, D. L. and Lovering, J. L. 2011., Effects of climate change and wave direction on longshore sediment transport patterns in Southern California, Climatic Change, 109, 211-228. DOI: 10.1007/s10584-011-0317-0

Assateague Island National Seashore (ASIS) 2012. ASIS shoreline data can be downloaded by contacting park personnel at http://www.nps.gov/asis/naturescience/resource-managementdocuments.htm.

Ashton, A., Murray, A. B. and Arnault, O. 2001. Formation of coastline features by large-scale instabilities induced by high-angle waves, Nature, 414, 296-300. 
Ashton, A. D., and Murray, A. B. 2006a. High-angle wave instability and emergent shoreline shapes: 1. Modeling of sand waves, flying spits, and capes, Journal of Geophysical Research, 111(F04011).

Ashton, A. D., and Murray A. B. 2006b. High-angle wave instability and emergent shoreline shapes: 2. Wave climate analysis and comparisons to nature, Journal of Geophysical Research: Earth Surface, 111(F4), 2156 - 2202.

Bromirski, P.D. and Kossin J.P. 2008. Increasing hurricane wave power along the U.S. Atlantic and Gulf coasts, Journal of Geophysical Research, 113 (C07012), doi:10.1029/JC004706

Cox, A.T. and Swail V.R. 2001. A global wave hindcast over the period 1958 - 1997: Validation and climate assessment, Journal of Geophysical Research, 106 (C2), pp. 2313 $-2329$

Dolan, R., Fenster, M.S. Holme, S.J. 1991. Temporal Analysis of Shoreline Recession and Accretion, Journal of Coastal Research, 7 (3), 723 - 744.

Ells, K., and Murray, A. B. 2012. Long-term, non-local coastline responses to local shoreline stabilization, Geophys. Res. Lett., 39(19), L19401.

Emanuel, K. 2005. Increasing destructiveness of tropical cyclones over the past 30 years, Nature, $436,686-688$.

Emanuel, K.A. 2013. Downscaling CMIP5 climate models shows increased tropical cyclone activity over the $21^{\text {st }}$ century, Proc. Nat. Acad. Sci., 110, doi/10.1073/pnas.1301293110. 
Ezer, T., Atkinson, L. P. Corlett, W. B. and Blanco, J. L. 2013. Gulf Stream's induced sea level rise and variability along the U.S. mid-Atlantic coast, Journal of Geophysical Research: Oceans, 118, 685-697.

Finkl, C.W., Becerra, J.E., Achatz, V. and Andrews, J.L. 2008. Geomorphological Mapping along the Upper Southeast Florida Atlantic Continental Platform; I: Mapping Units, Symbolization and Geographic Information System Presentation of Interpreted Seafloor Topography, Journal of Coastal Research, 24 (6) 1388 - 1417.

FitzGerald, D.M, Fenster, M.S., Argow, B.A., Buynevich, I.V. 2008. Coastal impacts due to sealevel rise, Annu. Rev. Earth Planet. Sci., 36, pp. 601-647, doi: 10.1146/annurev.earth.35.031306.140139

Fletcher, C.H., Romine, B.M., Genz, A.S., Barbee, M. M., Dyer, M., Anderon, T.R., Lim, S.C., Vitousek, S., Bochiccino, C. , Richmond, B. 2012. National Assessment of Shoreline Change: Historical Shoreline Change in the Hawaiian Islands. U.S. Geological Survey Open File Report 2011-1051.

Florida Fish and Wildlife (FF and W), Florida Shoreline (1:12,000). Marine Resources Geographic System Internet Map Server. http://ocean.floridamarine.org/mrgis/Description_Layers_Marine.htm

Gemmrich, J., Thomas, B., and Bouchard, R. 2011, Observational changes and trends in northeast Pacific wave records, Geophysical Research Letters, 38 (L22601), doi:10.1029/2011GL049518

Hapke, C.J., Katzmann, M.G., and Himmeltoss, E.A. 2013. Geomorphic and human influence on large-scale coastal change, Geomorphology, 199, 160 - 170 
Hayes, M.O. 1979. Barrier island morphology as a function of tidal and wave regime. In: Barrier Islands from the Gulf of St. Lawrence to the Gulf of Mexico, S.P. Leatherman (ed). New York: Academic Press. Pp. 1-27.

IPCC 2014. Sea Level Change. In Climate Change 2013: The Physical Science Basis.

Contribution of Working Group I to the Fifth Assessment Report of the Intergovernmental Panel on Climate Change, (New York, NY, USA: Cambridge University Press).

Kemp, A. C., Horton, B. P., Culver, S. J., Corbett, D. R., van de Plassche, O., Gehrels, W. R., Douglas, B. C., and Parnell, A. C., 2009. Timing and magnitude of recent accelerated sealevel rise (North Carolina, United States), Geology, 37(11), 1035-1038, doi:10.1130/g30352a.1.

Kline, S. W., Adams, P. N., and Plant, N. G. (In Review), Influence of complex inner-shelf bathymetry on the geomorphic evolution of a prominant cuspate foreland and adjacent shoreline, Journal of Geophysical Research - Earth Surface.

Knutson, T. R., McBride, J. L., Chan, J., Emanuel, K., Holland, G., Landsea, C., Held, I., Kossin, J. P., Srivastava, A. K. and Sugi, M. 2010. Tropical cyclones and climate change, Nature Geoscience, 3, 157 - 163.

Komar, P. D., and Allan, J. C., 2008. Increasing Hurricane-Generated Wave Heights along the U.S. East Coast and Their Climate Controls, Journal of Coastal Research, 24(2), 479-488, doi:10.2112/07-0894.1.

Leatherman, S. P., Rice, T. E., and Goldsmith, V. 1982. Virginia Barrier Island Configuration: A Reappraisal, Science, 215(4530), 285-287. 
Limber, P., List, J., Warren, J., Farris, A., and Weber, K. 2007. Using Topographic LIDAR Data to Delineate the North Carolina Shoreline. Coastal Sediments '07, 1837-1850. doi: $10.1061 / 40926(239) 144$

Lovejoy, D.W. 1983. The Anastasia Formation in Palm Beach and Martin counties, Florida. Miami Geological Society Memoir, 3, 58-72.

Magliocca, N. R., McNamara, D. E. and Murray, A. B. 2011. Long-Term, Large-Scale Morphodynamic Effects of Artificial Dune Construction along a Barrier Island Coastline, Journal of Coastal Research, 27(5), 918-930, doi:10.2112/jcoastres-d-10-00088.1.

McGranahan, Balk, G., D. and Anderson, B. 2007. The rising tide: assessing the risks of climate change and human settlements in low elevation coastal zones, edited, pp. 17-37, Environment and Urbanization, doi:10.1177/0956247807076960.

McNamara, D., Murray, A. B. and Smith, M. D. 2011. Coastal sustainability depends on how economic and coastline responses to climate change affect each other, Geophysical Research Letters, 38, doi:10.1029/2011GL047207.

McNamara, D. and Keeler, A. 2013. A coupled physical and economic model of the response of coastal real estate to climate risk, Nature Climate Change, 3, pp. 559 - 562, doi:10.1038/nclimate1826

Moore, L. J. 2000, Shoreline mapping techniques, Journal of Coastal Research, 16(1), 111-124.

Moore, L. J., List, J. H., Williams, S. J. and Stolper, D. 2010. Complexities in barrier island response to sea level rise: Insights from numerical model experiments, North Carolina Outer 
Banks, Journal of Geophysical Research-Earth Surface, 115, doi:F0300410.1029/2009jf001299.

Moore, L. J., McNamara, D.E., Murray, A.B, and Brenner, O. 2013. Recent Shifts in Large-Scale Coastline Erosion Patterns Linked to Storm Climate Change, Geophysical Research Letters.

Moore, L. J., Ruggiero, P. and List, J. H. 2006. Comparing mean high water and high, water line shorelines: Should proxy-datum offsets be incorporated into shoreline change analysis, Journal of Coastal Research, 22(4), 894-905, doi:10.2112/104-0401.1.

Morton, R. A. and Miller, T.L., 2005. The National Assessment of Shoreline Change Part 2: Historical Shoreline Change and Associated Land Loss along the U.S. Southeast Atlantic Coast: U.S. Geological Survey Open File Report 2005-1401.

National Aerounatics and Space Administration (NASA) 2010. Wallops Island VA Wallops Flight Center, Storm Damage Reduction Project Design for Wallops Island, Virginia (January 2010). Retrieved from http://sites.wff.nasa.gov/code250/docs/SRIPP_EIS_Appendix_A.pdf.

National Oceanic and Atmospheric Administration (NOAA) 2012. National Geodetic Survey NOAA Shoreline Data Explorer, [URL:http://www.ngs.noaa.gov/newsys_ims/shoreline/index.cfm].

North Carolina Department of Earth and Environment - Division of Coastal Management 2011. Oceanfront shorelines [Data file(s): 1998, 2003, 2004] Retrieved from http://dcm2.enr.state.nc.us/Maps/chdownload.htm\#Oceanfront\%20Shorelines. 
Nummedal, D., Oertel, G.F., Hubbard, D.K. and Hine, A.C., 1977. Tidal inlet variability - Cape Hatteras to Cape Canaveral:American Society of Civil Engineers, Coastal Sediments '77, p. 543-562.

Oster, D. 2012. Beach Morphology of the Virginia Barrier Islands 1998, 2005 and 2009. Virginia Coast Reserve Long-Term Ecological Research Project Data Publication knb-lter-vcr.204.6 (http://metacat.lternet.edu/knb/metacat/knb-lter-vcr.204.6/lter).

Pilkey, O. H., Neal, W. J., Riggs, S. R. Webb, C. A., Bush, D. M., Pilkey, D. F., Bullock, J. and Cowan, B. A. 1998. The North Carolina shore and its barrier islands, restless ribbons of sand, Duke University Press, Durham.

Program for the Study of Developed Shorelines (PSDS) 2012. Inventory of Coastal Engineering. [Data File(s): beachnourishment.zip] Retrieved from http://www.wcu.edu/9165.asp

Riggs, S. R., Cleary, W.J. and Snyder, S. W. 1995. Influence of inherited geological framework on barrier shoreface morphology and dynamics, Marine Geology, 126, 213-234.

Rink, W. J., and Forrest, G. 2005. Dating Evidence for the Accretion History of Beach Ridges on Cape Canaveral and Merritt Island, Florida, USA, Journal of Coastal Research, 21(5), 1000-1008.

Ruggiero, P., M., Buijsman, M., Kaminsky, G.M. and Gelfenbaum, G. 2010. Modeling the effects of wave climate and sediment supply variability on large-scale shoreline change, Marine Geology, 273, pp. 127- 140 
Sallenger Jr., A. H., Doran, K. S. and Howd, P. A. 2012. Hotspot of accelerated sea-level rise on the Atlantic coast of North America, Nature Climate Change, 2, 884 - 888.

Slott, J. M., Murray, A.B. and Ashton, A.D. 2010. Large-scale responses of complex-shaped coastlines to local shoreline stabilization and climate change, Journal of Geophysical Research-Earth Surface, 115, doi:F0303310.1029/2009jf001486.

Slott, J. M., Murray, A. B., Ashton, A. D. and Crowley, T. J. 2006. Coastline responses to changing storm patterns, Geophysical Research Letters, 33(18), doi:L1840410.1029/2006g1027445.

Southgate, H. G. 1995. The effects of wave chronology on medium and long term coastal morphology, Coastal Engineering 26, 251-271.

Sterl, A., and Caires, S. 2005. Climatology, variability and extrema of ocean waves: The webbased KNMI/ERA-40 wave atlas, Int. J. Climatol., 25, pp. 963 - 977.

Thieler, E.R., Himmelstoss, E.A., Zichichi, J.L., and Ergul, A, 2008. Digital Shoreline Analysis System (DSAS) version 4.0-An ArcGIS extension for calculating shoreline change: U.S. Geological Survey Open-File Report 2008-1278.

USACE, 1965. Carolina Beach and Vicinity, Carolina Beach Portion (Coastal Storm Damage Reduction Program), Department of the Army, U.S. Corps of Engineers: Wilmington, NC.

USACE, 1998. Carolina Beach and Vicinity, NC Area South, Kure Beach (Coastal Storm Damage Reduction Program), Department of the Army, U.S. Corps of Engineers: Wilmington, NC. 
United State Geological Survey (USGS) 2012. The National Assessment of Shoreline Change: A GIS Compilation of Vector Shorelines and Associated Shoreline Change Data for the New England and Mid-Atlantic Coasts. Open File Report 2010-1119[Data File(s):

DelmarvaN_shorelines.shp, DelmarvaS_shorelines.shp] Retrieved from http://pubs.usgs.gov/of/2010/1119/data_catalog.html.

United States Geological Survey (USGS) 2011. The National Assessment of Shoreline Change: A GIS Compilation of Vector Shorelines and Associated Shoreline Change Data for the U.S. Southeast Atlantic Coast. Open File Report 2005-1326. [Data file: nc_zip]. Retrieved from http://pubs.usgs.gov/of/2005/1326/gis-data.html.

Valverde, H. R., Trembanis, A.C.and Pilkey, O. H. 1999. Summary of beach nourishment episodes on the US East Coast barrier islands, Journal of Coastal Research, 15(4), 11001118.

Wallops Island Flight Facility (WFF) 2011. NASA Seawall Extension at Wallops Island, VA, U.S Army Corps of Engineers Solicitation Number: W91236-11-B-0011, USACE District, Norfolk, Retrieved from www.fbo.gov.

Wallops Island Flight Facility (WFF) 2010. Large ocean dredging and beach nourishment at significant distances (15 to $20 \mathrm{NM}$ ) from the Wallops Island coastline to be nourished and protected, U.S Army Corps of Engineers Solicitation Number: W91236-10-R-0026, USACE District, Norfolk, Retrieved from www.fbo.gov. 
Webster, P. J., Holland, G.J., Curry, J.A. and Chang, H.R. 2005. Changes in Tropical Cyclone Number, Duration, and Intensity in a Warming Environment, Science, 309(5742), 18441846.

Wolner, C.W.V, Moore, L.J., Young, D.R., Brantley, S.T., Bissett, S.N., McBride, R. A. 2013. Ecomorphodynamic feedbacks and barrier island response to disturbance: Insights from the Virginia Barrier Islands, Mid-Atlantic Bight, USA. Geomorphology, doi:

10.1016/j.geomorph2013.03035, accepted manuscript.

Woodruff, J.D., Irish, J.L., Camargo, S.J., 2013. Coastal Flooding by tropical cyclones and sea level rise, Nature, 504, doi:10/1038/nature12855

Work, P., and Dean, R.G., 1990. Shoreline Changes Adjacent to Florida's East Coast Tidal Inlets, University of Florida, Coastal and Oceanographic Engineering Department. 
Johnson, et al., in press, Earth Surface Processes and Landforms

\section{Tables}

Table 1. Digital Shoreline Data Summary. Legend: P - shoreline provides partial coverage of study area. F - shoreline provides full coverage of study area. MD DNR - Maryland Department of Natural Resources. NAPP - National Aerial Photography Program. FL DOT- Florida Department of Transportation. FL DEP - Florida Department of Environmental Protection. ${ }^{1}$ Morton \& Miller, 2005, ${ }^{2}$ Limber et al., 2007, ${ }^{3}$ Hapke et al., 2010, ${ }^{4}$ ASIS, 2011, ${ }^{*}$ assigned by data source according to ref. $1,{ }^{\wedge}$ calculated using applicable values reported in Table $3 ;{ }^{+}$estimated conservatively based on aerial photo data source because no uncertainty data was available. 


\begin{tabular}{|c|c|c|c|c|c|}
\hline Year(s) & Source Agency & Orig. Media & Datum/Proxy & Extent & Uncertainty \\
\hline \multicolumn{6}{|c|}{ Cape Fear } \\
\hline \multicolumn{6}{|l|}{ Historic: } \\
\hline $1849-1873$ & USGS & T-sheets & HWL & $\mathrm{F}$ & $\pm 10.8^{1}$ \\
\hline $1877-1878$ & NOAA & T-sheets & Nat. HWL & $P$ & $\pm 10.8^{*}$ \\
\hline 1914 & NOAA & T-sheets & Nat. HWL & $\mathrm{P}$ & $\pm 10.8^{*}$ \\
\hline $1933-1934$ & USGS & T-sheets & HWL & $\mathrm{F}$ & $\pm 10.8^{1}$ \\
\hline $1936-1937$ & NOAA & T-sheets & Nat. HWL & $\mathrm{P}$ & $\pm 10.8^{*}$ \\
\hline $1942-1944$ & USGS & T-sheets & Nat. HWL & $\mathrm{P}$ & $\pm 10.8^{1}$ \\
\hline $1962-1969$ & NOAA & T-sheets & Nat. HWL & $\mathrm{P}$ & $\pm 10.8^{*}$ \\
\hline \multicolumn{6}{|l|}{ Recent: } \\
\hline $1970-1973$ & USGS & T-sheets & HWL & $\mathrm{F}$ & $\pm 5.1^{1}$ \\
\hline 1997 & USGS & LiDAR & LiDAR MHWL & $\mathrm{F}$ & $\pm 3.8^{\wedge}$ \\
\hline 1998 & NC DENR & Aerial Photos & Wet-Dry Line & $\mathrm{F}$ & $\pm 10.4^{2}$ \\
\hline 2003 & NC DENR & Aerial Photos & Wet-Dry Line & $\mathrm{F}$ & $\pm 10.4^{2}$ \\
\hline 2004 & NC DENR & Aerial Photos & Wet-Dry Line & $\mathrm{F}$ & $\pm 10.4^{2}$ \\
\hline \multicolumn{6}{|c|}{ Fishing Point } \\
\hline \multicolumn{6}{|l|}{ Historic: } \\
\hline $1849-1852$ & USGS & T-sheets & HWL & $\mathrm{F}$ & $\pm 11.7^{3}$ \\
\hline $1859-1887$ & USGS & T-sheets & HWL & $\mathrm{P}$ & $\pm 11.7^{3}$ \\
\hline $1908-1910$ & USGS & T-sheets & HWL & $\mathrm{P}$ & $\pm 11.7^{3}$ \\
\hline 1933 & USGS & T-sheets & HWL & $\mathrm{P}$ & $\pm 11.7^{3}$ \\
\hline $1942-1943$ & USGS & T-sheets & HWL & $\mathrm{F}$ & $\pm 11.7^{3}$ \\
\hline 1962 & USGS & T-sheets & HWL & $\mathrm{F}$ & $\pm 6.8^{3}$ \\
\hline \multicolumn{6}{|l|}{ Recent: } \\
\hline 1980 & USGS & Aerial Photos & HWL & $\mathrm{P}$ & $\pm 5.5^{3}$ \\
\hline 1989 & USGS & T-sheets & HWL & $\mathrm{P}$ & $\pm 5.5^{3}$ \\
\hline 1995 & ASIS & GPS & Wet-Dry Line & $\mathrm{P}$ & $\pm 1^{4}$ \\
\hline 1997 & ASIS / Oster (2012) & GPS / LiDAR & W-D Line / LiDAR MHWL & $\mathrm{F}$ & $\pm 1^{4} / \pm 15.4^{\wedge}$ \\
\hline 1998 & ASIS / Oster (2012) & GPS / LiDAR & W-D Line / LiDAR MHWL & $\mathrm{F}$ & $\pm 1^{4} / \pm 15.4^{\wedge}$ \\
\hline 2005 & ASIS / Oster (2012) & GPS / LiDAR & W-D Line / LiDAR MHWL & $\mathrm{F}$ & $\pm 1^{4} / \pm 15.4^{\wedge}$ \\
\hline 2009 & ASIS / Oster (2012) & GPS / LiDAR & W-D Line / LiDAR MHWL & $\mathrm{F}$ & $\pm 1^{4} / \pm 15.4^{\wedge}$ \\
\hline 2010 & ASIS & GPS & Wet-Dry Line & $\mathbf{P}$ & $\pm 1^{4}$ \\
\hline \multicolumn{6}{|c|}{ Cape Canaveral } \\
\hline \multicolumn{6}{|l|}{ Historic: } \\
\hline $1851-1884$ & USGS & T-sheets & HWL & $\mathrm{F}$ & $\pm 10.8^{1}$ \\
\hline $1923-1930$ & USGS & T-sheets & HWL & $\mathrm{F}$ & $\pm 10.8^{1}$ \\
\hline 1943 & NAPP/NASA & Aerial Photos & MHW & $\mathbf{P}$ & $\pm 3.0^{\wedge}$ \\
\hline 1947 & NOAA & T-sheets & Nat. HWL & $\mathrm{P}$ & $\pm 10.8^{*}$ \\
\hline 1951 & NAPP/NASA & Aerial Photos & MHW & $\mathbf{P}$ & $\pm 3.3^{\wedge}$ \\
\hline 1958 & NAPP/NASA & Aerial Photos & MHW & $\mathrm{P}$ & $\pm 3.1^{\wedge}$ \\
\hline 1964 & NOAA & Aerial Photos & Nat. HWL & $\mathrm{P}$ & $\pm 5.1^{*}$ \\
\hline $1966-1967$ & NOAA & Aerial Photos & Nat. HWL & $\mathrm{F}$ & $\pm 5.1^{*}$ \\
\hline \multicolumn{6}{|l|}{ Recent: } \\
\hline $1969-1970$ & NOAA & Aerial Photos & Nat. HWL & $\mathrm{P}$ & $\pm 5.1^{*}$ \\
\hline 1994 & NAPP & Aerial Photos & MHW & $\mathrm{P}$ & $\pm 3.3^{\wedge}$ \\
\hline 1999 & USGS & LiDAR & LiDAR MHWL & $\mathrm{F}$ & $\pm 22.1^{1}$ \\
\hline 2000 & Kucera Int. & Aerial Photos & MHW & $\mathrm{P}$ & $\pm 3.4^{\wedge}$ \\
\hline 2002 & DigitalGlobe, Inc. & Ikonos & MHW & $\mathrm{P}$ & $\pm 3.3^{\wedge}$ \\
\hline 2003 & NAPP & Aerial Photos & MHW & $\mathrm{P}$ & $\pm 3.3^{\wedge}$ \\
\hline 2004 & FF and $\mathrm{W}$ & Aerial Photos & MHW & $\mathrm{F}$ & $\pm 3.3^{\wedge}$ \\
\hline 2005 & FL DOT & Aerial Photos & MHW & $\mathrm{P}$ & $\pm 2.9^{\wedge}$ \\
\hline 2006 & FL DEP & Aerial Photos & MHW & $\mathrm{P}$ & $\pm 2.9^{\wedge}$ \\
\hline 2007 & Ariels Express, Inc & Aerial Photos & MHW & $\mathrm{P}$ & $\pm 2.5^{\wedge}$ \\
\hline 2009 & DigitalGlobe, Inc. & Geoeye1 & MHW & $\mathrm{P}$ & $\pm 3.2^{\wedge}$ \\
\hline 2010 & DigitalGlobe, Inc. & Geoeye1 & MHW & $\mathrm{P}$ & $\pm 2.8^{\wedge}$ \\
\hline
\end{tabular}


Table 2. The percentage of coastline along which at least three shorelines were available (within each study area, for the historic and recent shoreline change rate analyses), allowing a linear regression rate (LRR) to be calculated. Along the remaining percentage of coastline (within each study area, for the historic and recent shoreline change rate analyses), end point rates (EPR) were calculated instead.

\begin{tabular}{|lcc|}
\hline Historic & \%LRR & \%EPR \\
\hline Cape Fear & 60 & 40 \\
Fishing Point & 100 & 0 \\
Cape Canaveral & 72 & 28 \\
\hline Recent & \%LRR & \%EPR \\
\hline Cape Fear & 100 & 0 \\
Fishing Point & 95 & 5 \\
Cape Canaveral & 72 & $\mathbf{2 8}$ \\
\hline
\end{tabular}

Table 3. Error estimates used to calculate uncertainty values (indicated by ${ }^{\wedge}$ in Table 1 ) for shorelines provided without associated uncertainty values or that were generated by the authors of this study.

\begin{tabular}{|c|c|c|}
\hline Source of Error & $\begin{array}{c}\text { Error } \\
\text { Estimate } \\
\text { (m) }\end{array}$ & Source of Estimate \\
\hline \multicolumn{3}{|c|}{ North Carolina - Lidar Shoreline Uncertainties } \\
\hline Shoreline-Proxy Offset & \pm 3.53 & Limber et al., 2007 (specific to North Carolina) \\
\hline $\begin{array}{l}\text { LiDAR positional } \\
\text { uncertainty- NC }\end{array}$ & \pm 1.5 & Stockdon et al., 2002 \\
\hline \multicolumn{3}{|c|}{ Fishing Point - Lidar Shoreline Uncertainties } \\
\hline Shoreline-Proxy Offset & \pm 15.25 & $\begin{array}{l}\text { Calculated from values in Morton \& Miller (2005), Table 5, } \\
\text { values for MD\&VA only }\end{array}$ \\
\hline LiDAR positional uncertainty & \pm 2.3 & Hapke et al., 2010 \\
\hline \multicolumn{3}{|c|}{ Cape Canaveral - Aerial Photo Shoreline Uncertainties } \\
\hline Digitization & \pm 1 & Estimated by analyst \\
\hline Pixel Error & $\max = \pm 1$ & Pixel size in digital image \\
\hline Georeferencing & $\pm 1.5-4.04$ & RMS values for each rectification \\
\hline
\end{tabular}


Table 4. Average uncertainties associated with filtered shoreline change rate calculations shown in Figures 10 - 12).

\begin{tabular}{|c|c|c|c|}
\hline & $\mathrm{U}_{\text {avg }} \operatorname{Min} .(\mathrm{m} / \mathrm{yr})$ & $\mathrm{U}_{\text {avg }} \operatorname{Max}(\mathrm{m} / \mathrm{yr})$ & Uavg Avg. (m/yr) \\
\hline Cape Fear & \pm 0.06 & \pm 8.25 & \pm 0.49 \\
\hline Fishing Point & \pm 0.06 & \pm 20.06 & \pm 0.81 \\
\hline Cape Canaveral & \pm 0.06 & \pm 2.55 & \pm 0.48 \\
\hline
\end{tabular}




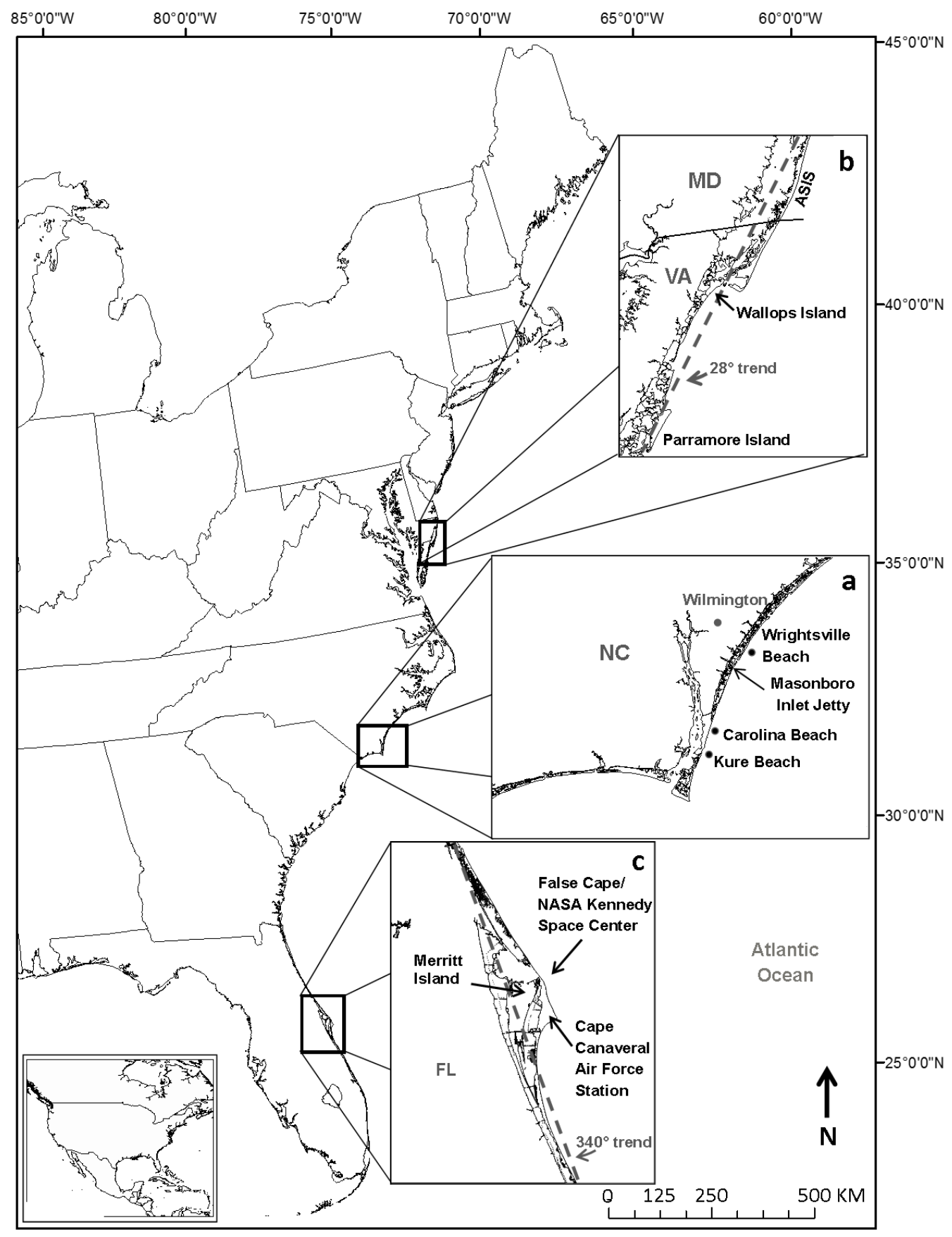

Figure 1. Study area map. (a) Cape Fear, North Carolina. (b) Fishing Point, VA \& MD. and (c) Cape Canaveral, FL. 


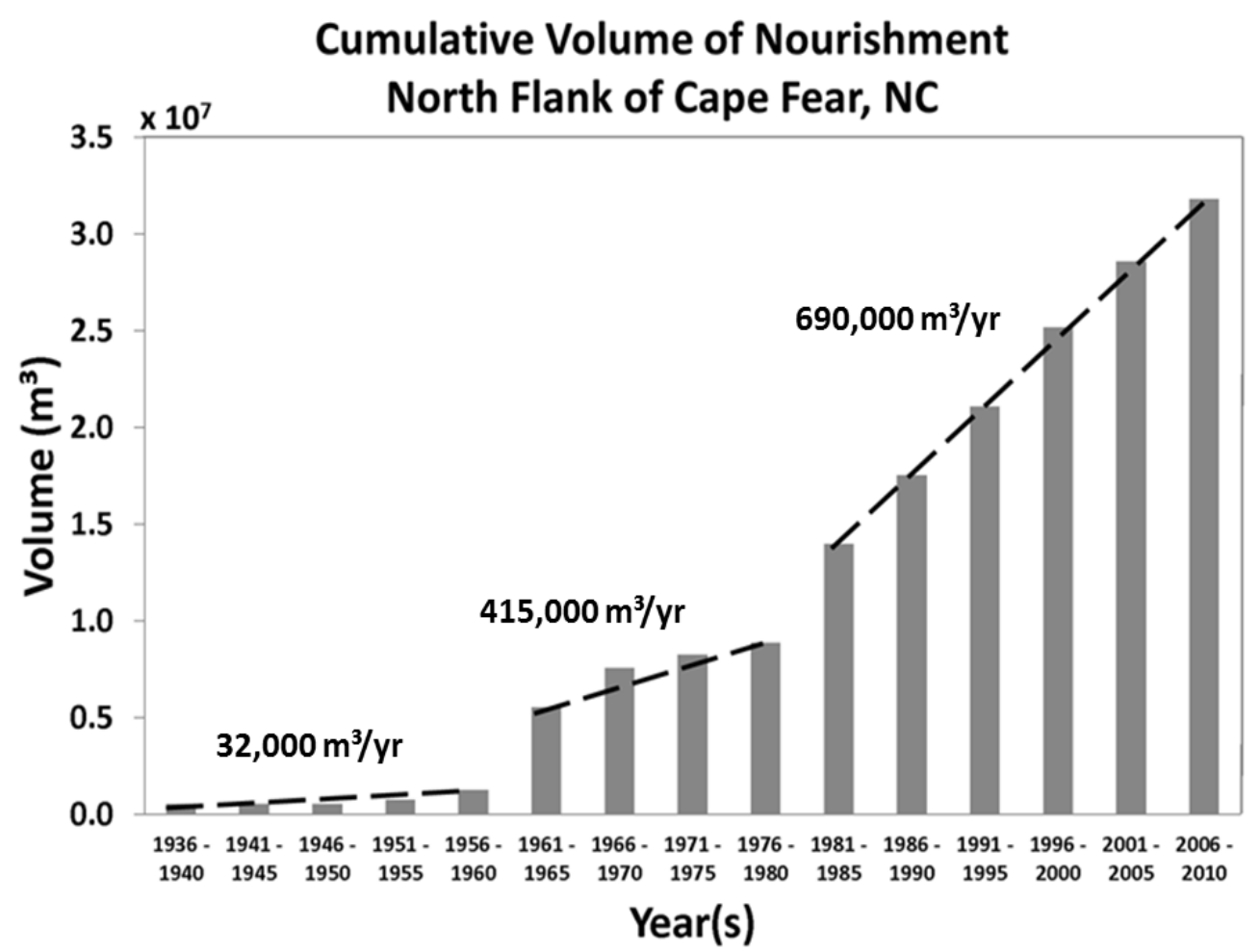

Figure 2. Cumulative beach nourishment volume for the northern flank of Cape Fear binned in 5-year increments. Three different rates of nourishment are indicated by dashed, black lines. 

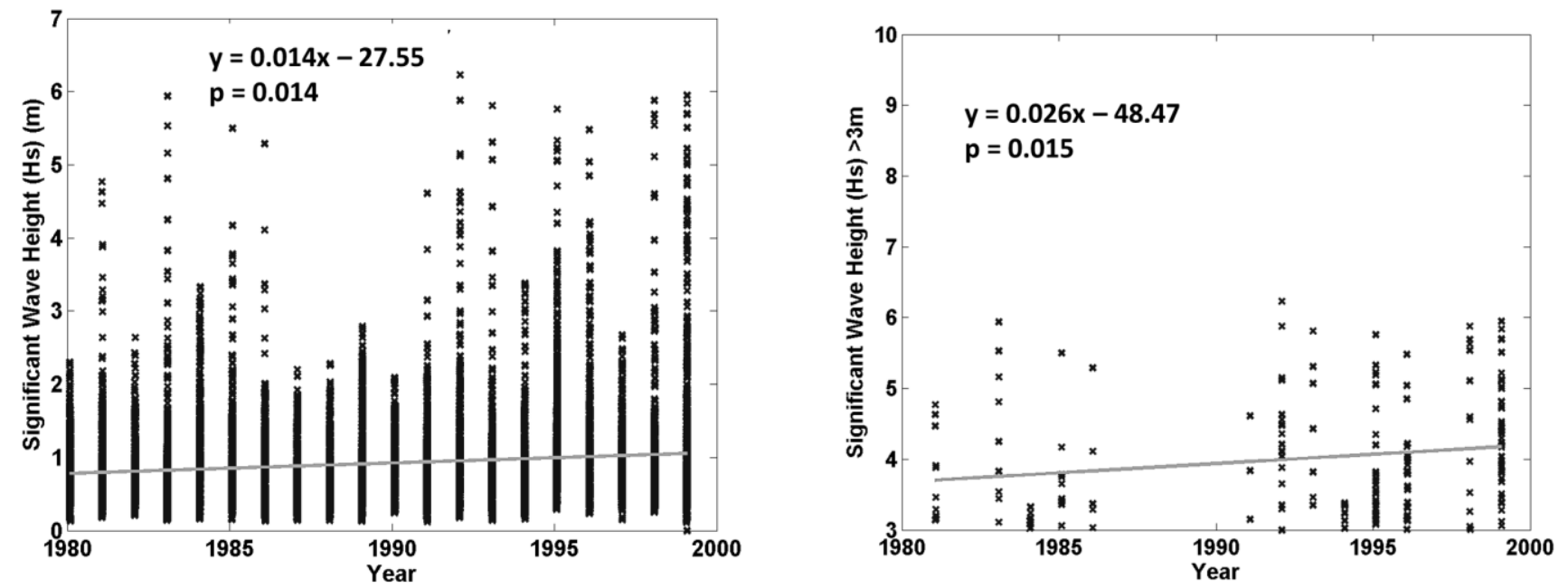

Figure 3. Representative plot of (a) increases in summer season significant wave height and (b) hurricanegenerated waves $(>3 \mathrm{~m}$ ) off the coast of Fishing Point, MD \& VA from WIS Station 63177. Trends are significant at the $95 \%$ confidence level using the Wilcoxon rank-sum test. Note that values shown are derived from this WIS station alone and therefore differ slightly from the average values for Fishing Point reported in the text. 

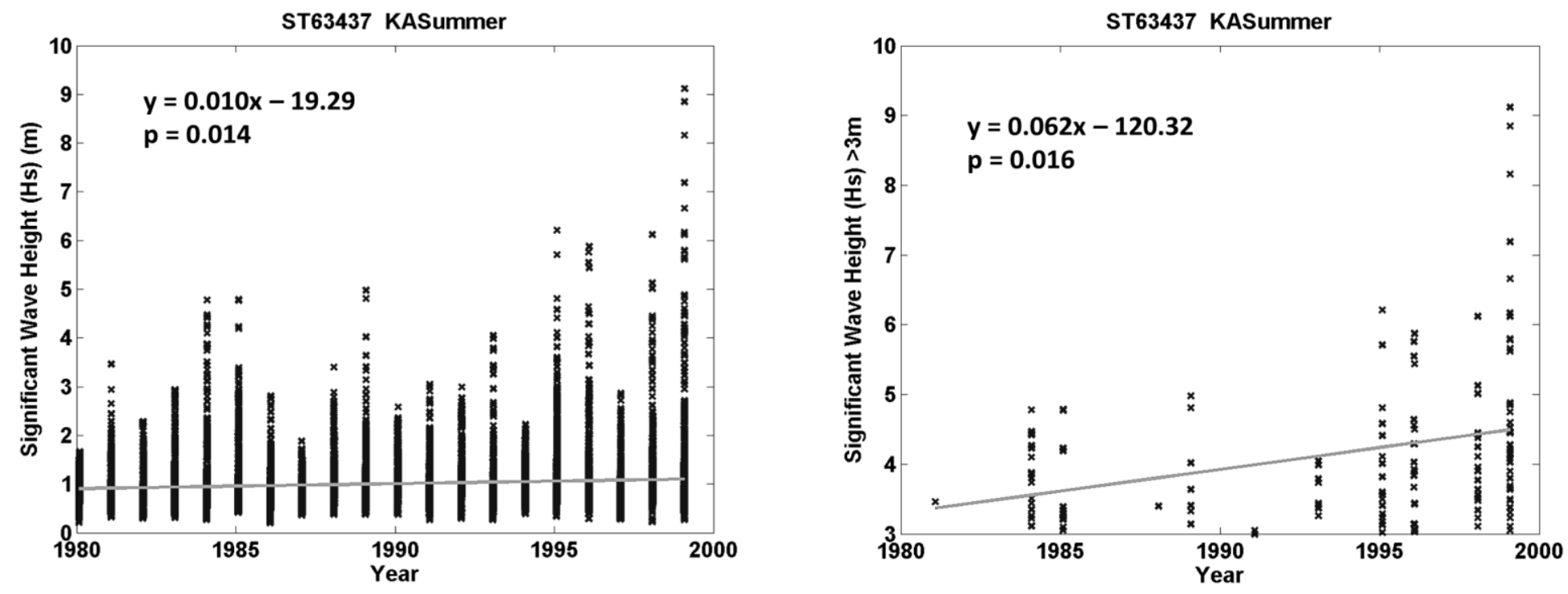

Figure 4. Representative plot of (a) increases in summer season (July - September) significant wave height and (b) hurricane-generated waves off the coast of Cape Canaveral, FL from WIS Station 63437. Trends are significant at the 95 confidence level using the Wilcoxon rank-sum test. Note that values shown are derived from this WIS station alone and therefore differ slightly from the average values for Cape Canaveral reported in the text. 

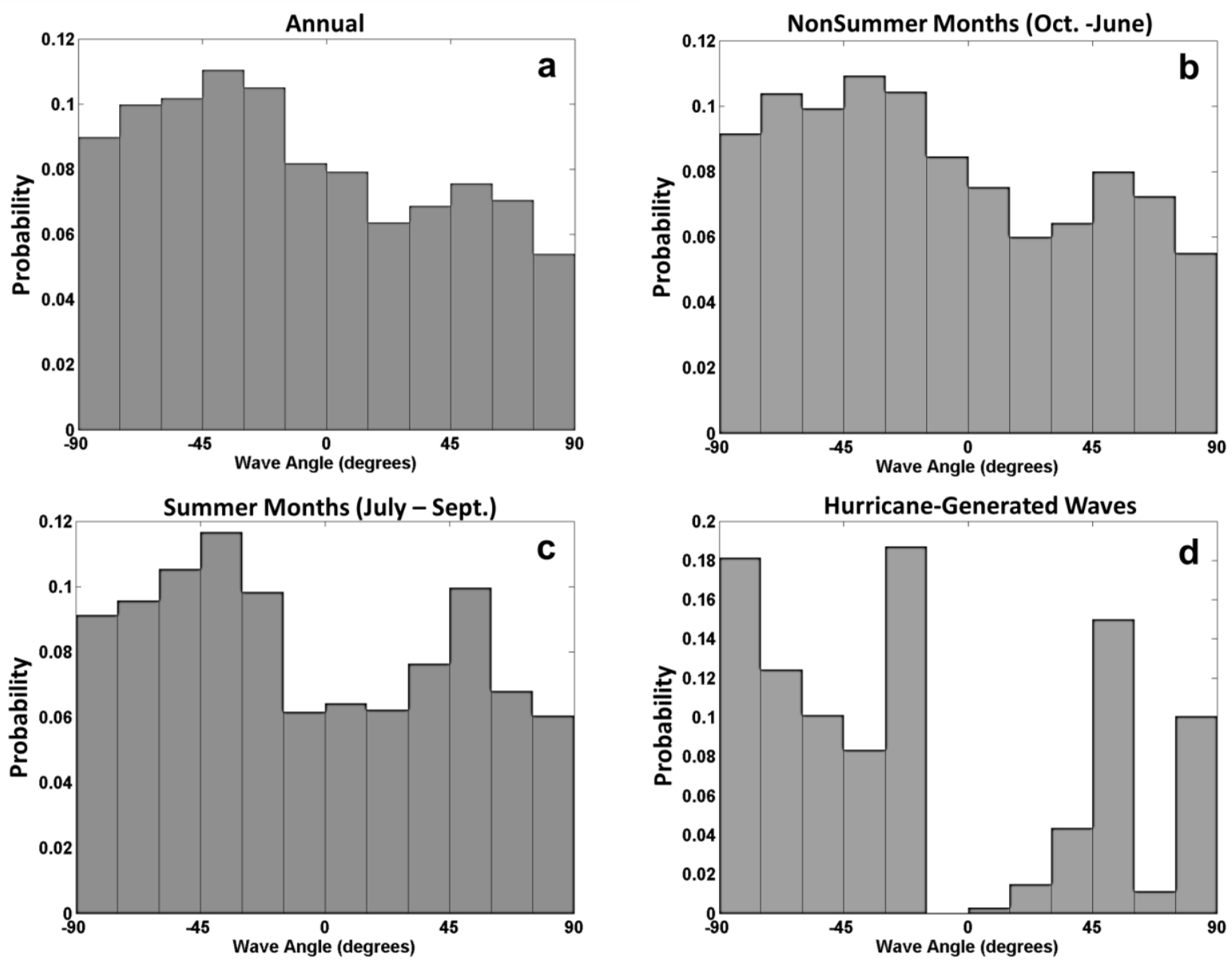

Figure 5. Representative wave climate off the coast of Fishing Point from WIS station 63177. Annual wave climate (a) and the non-summer wave climate (b) are bimodal with a high influence of waves from the left (north). (c) In the summer, the distribution becomes more bimodal and there is a greater influence of waves from the south. Hurricane-generated waves (d) approach from predominantly high angles (i.e., from northeast/east and south). 

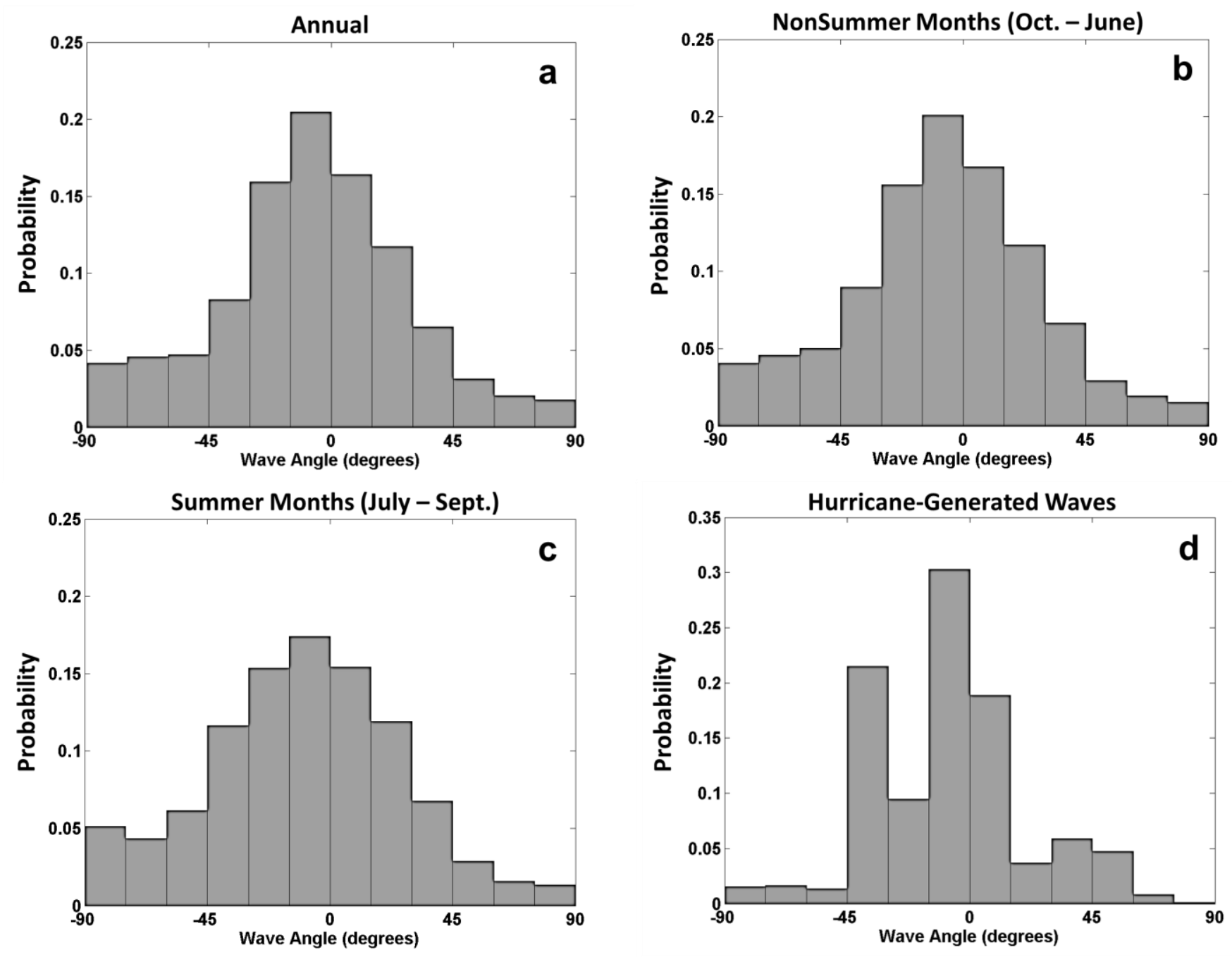

Figure 6. Representative wave climate in the vicinity of Cape Canaveral based on WIS Station 63437. The annual wave climate (a) and non-summer wave climate (b) are dominantly low-angle and slightly asymmetric, with a greater influence of waves approaching from the left (north relative to the general shoreline trend). Summer season waves (c) have an increased asymmetry with more waves approaching from the left (north) relative to other months of the year, and the hurricane-generated waves (those $>3 \mathrm{~m}$ ) (d) appear to approach from low-angles and the left (east). 


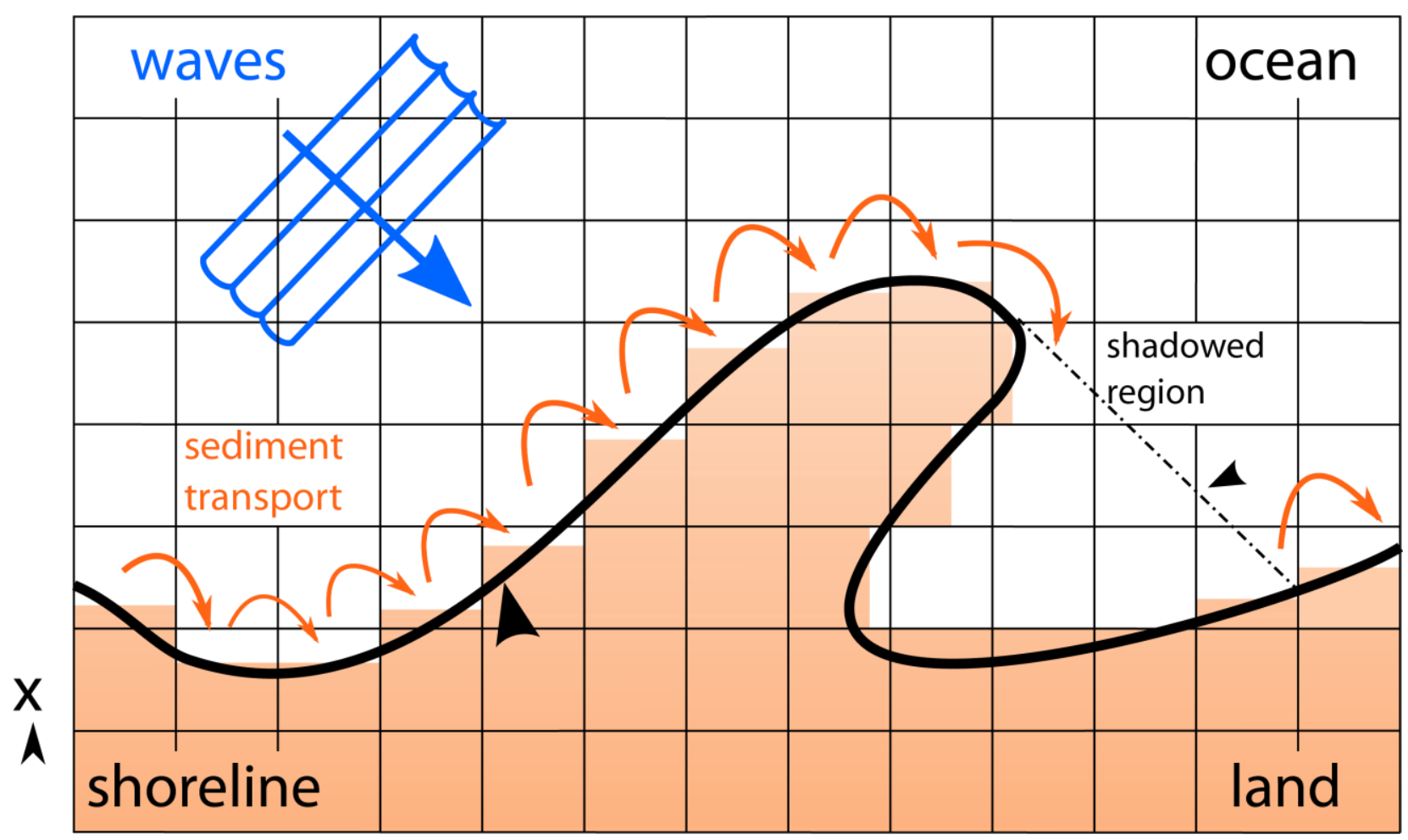

$>y$

Figure 7. Schematic illustration of the Coastline Evolution Model (CEM). Gradients in alongshore sediment fluxes, related to the local shoreline angle relative to offshore wave-approach angles (which change every model day according to a probability distribution function representing a wave climate), cause changes in shoreline position. Within geometric wave shadows, alongshore sediment transport does not occur (after Ashton and Murray, 2006a). 


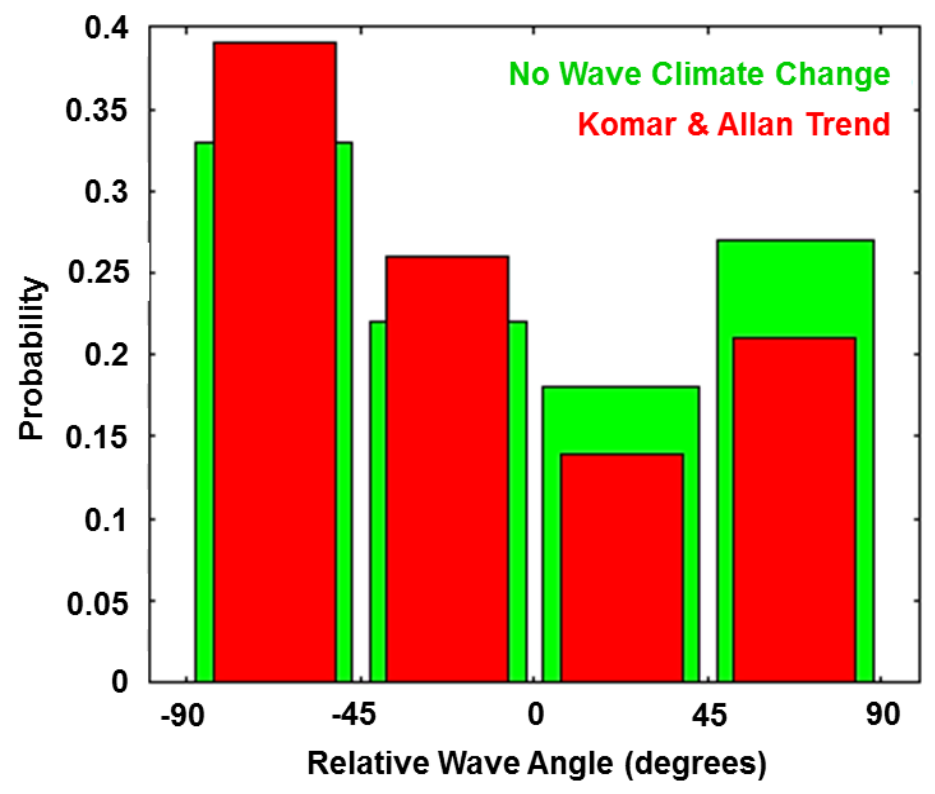

Figure 8. Wave climate probability distribution functions (of wave angle relative to general shoreline trend) used in model simulations. Green bins approximate WIS hindcast data and red bins represent a wave climate reflective of an increase in hurricane-generated waves, consistent with observations by Komar \& Allan (2008).

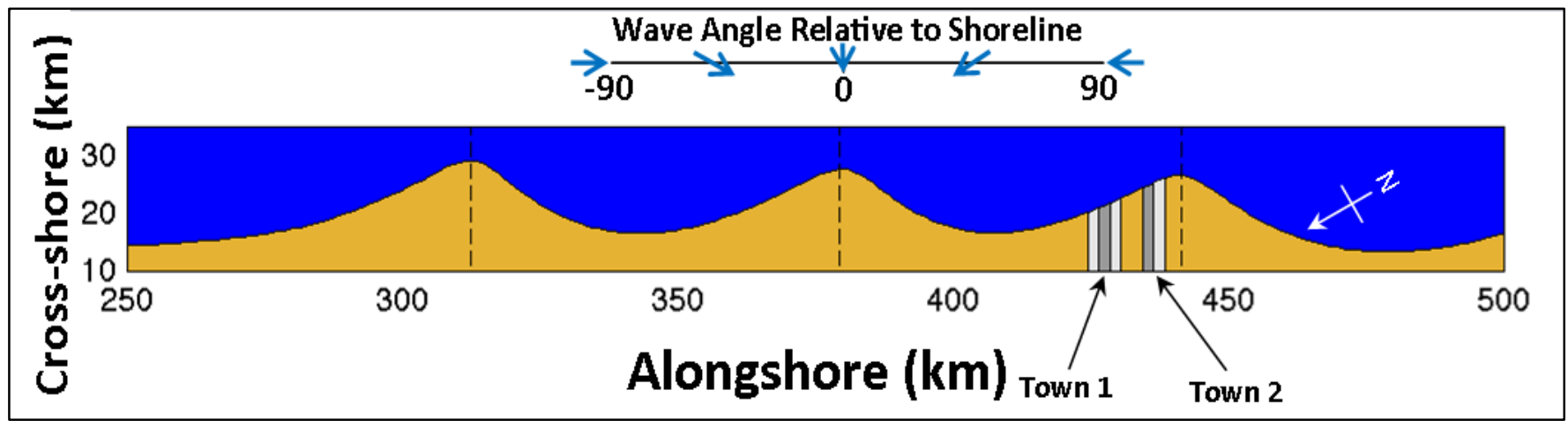

Figure 9. Initial condition for model simulations. Placement of Town 1 and Town 2 approximates the locations of Wrightsville and Carolina/Kure Beach, respectively. 
$78^{\circ} 0^{\prime} \mathrm{W}$

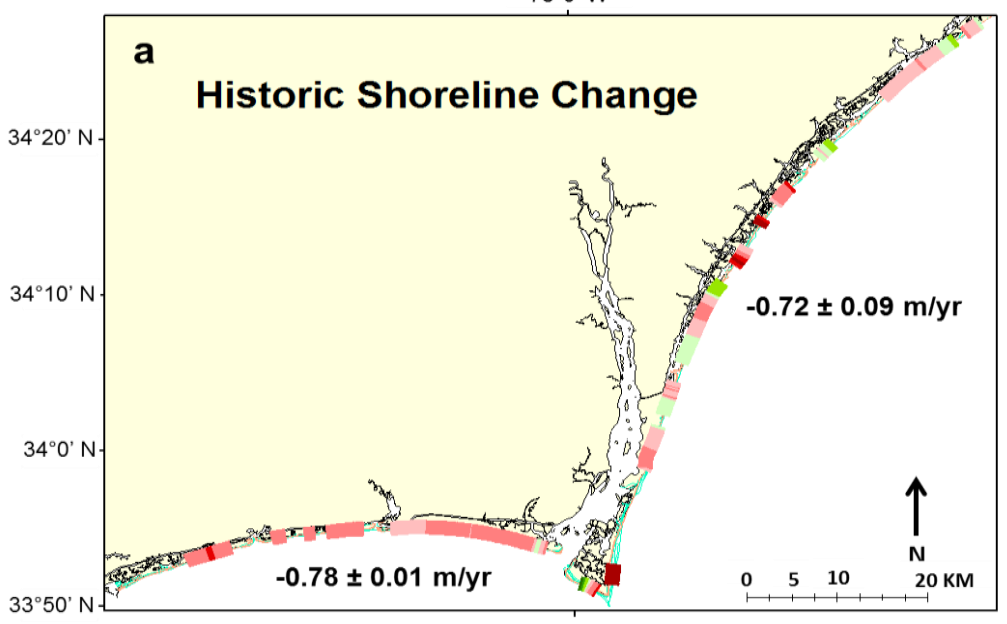

$78^{\circ} 0^{\prime} \mathrm{W}$

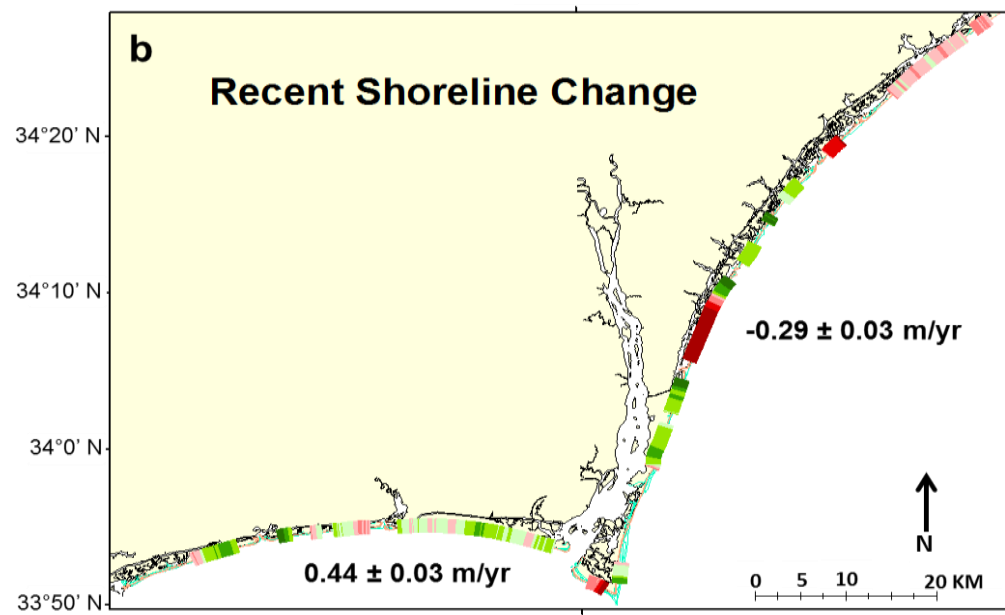

$78^{\circ} 0^{\prime} \mathrm{W}$

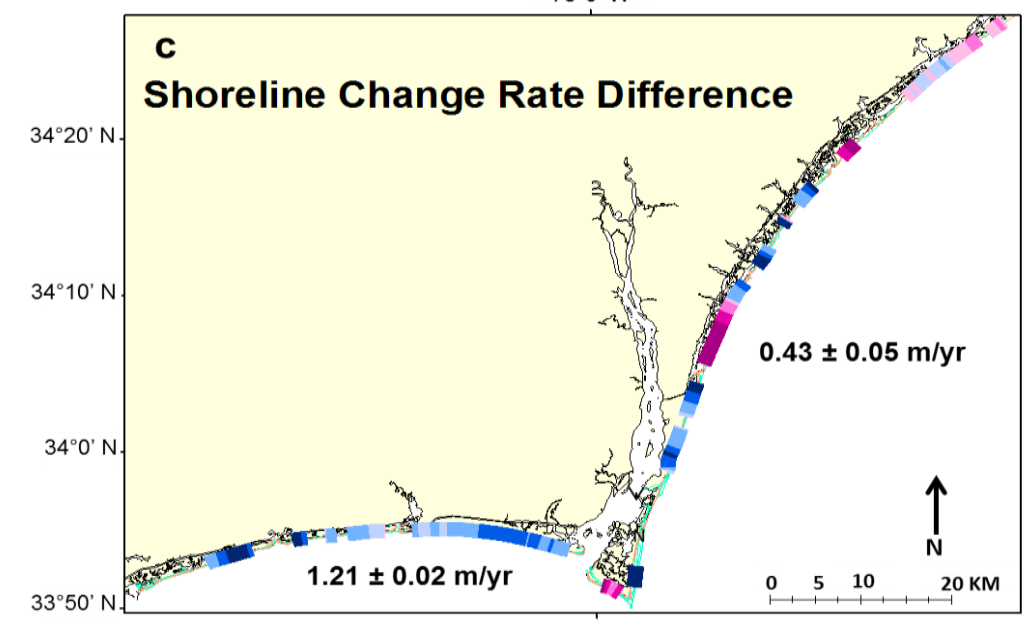

Shoreline Change Rates (m/yr)

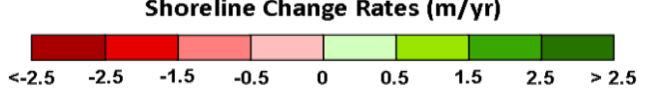

Rate Differences ( $\mathrm{m} / \mathrm{yr}$ )

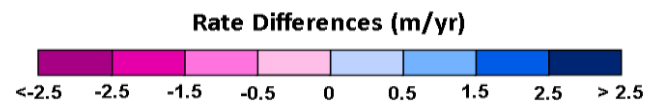

Figure 10. Shoreline change analysis for Cape Fear, NC. Shoreline change rates for (a) historic and (b) recent time periods. Red shades represent negative (erosional) rates while green shades are positive (accretional) values. Shoreline change rate difference (c), calculated by subtracting historic rates from the recent rates. Blue shades indicate areas that have become increasingly accretional in the recent while areas of purple shades have become increasingly erosional. Average rates and associated uncertainties are shown for each cape flank. Shorelines are plotted below rates of change to delineate general coastline trend. 

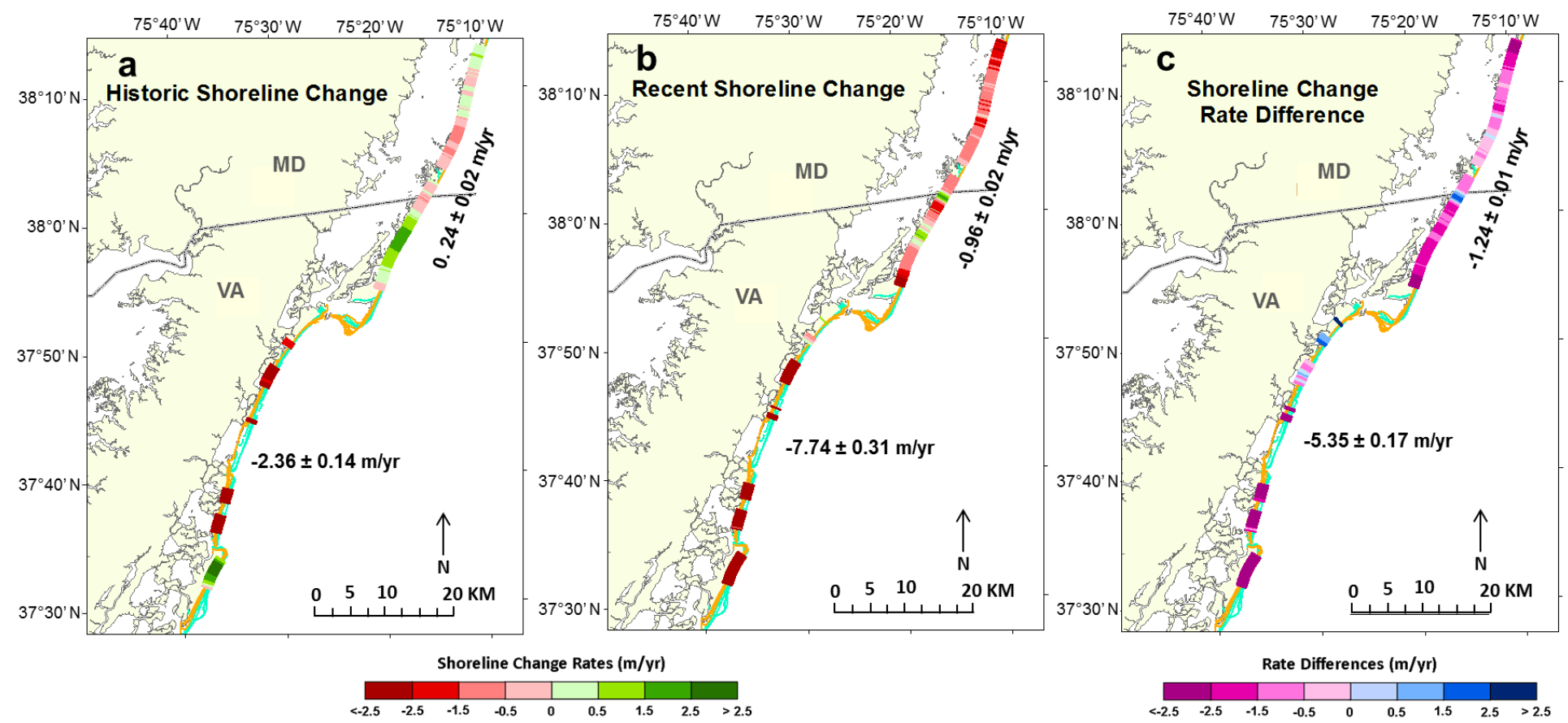

Figure 11. Shoreline change analysis for Fishing Point, MD\&VA. Colors represent same values as in Figure 10. Shorelines are plotted below rates of change to delineate general coastline trend. 

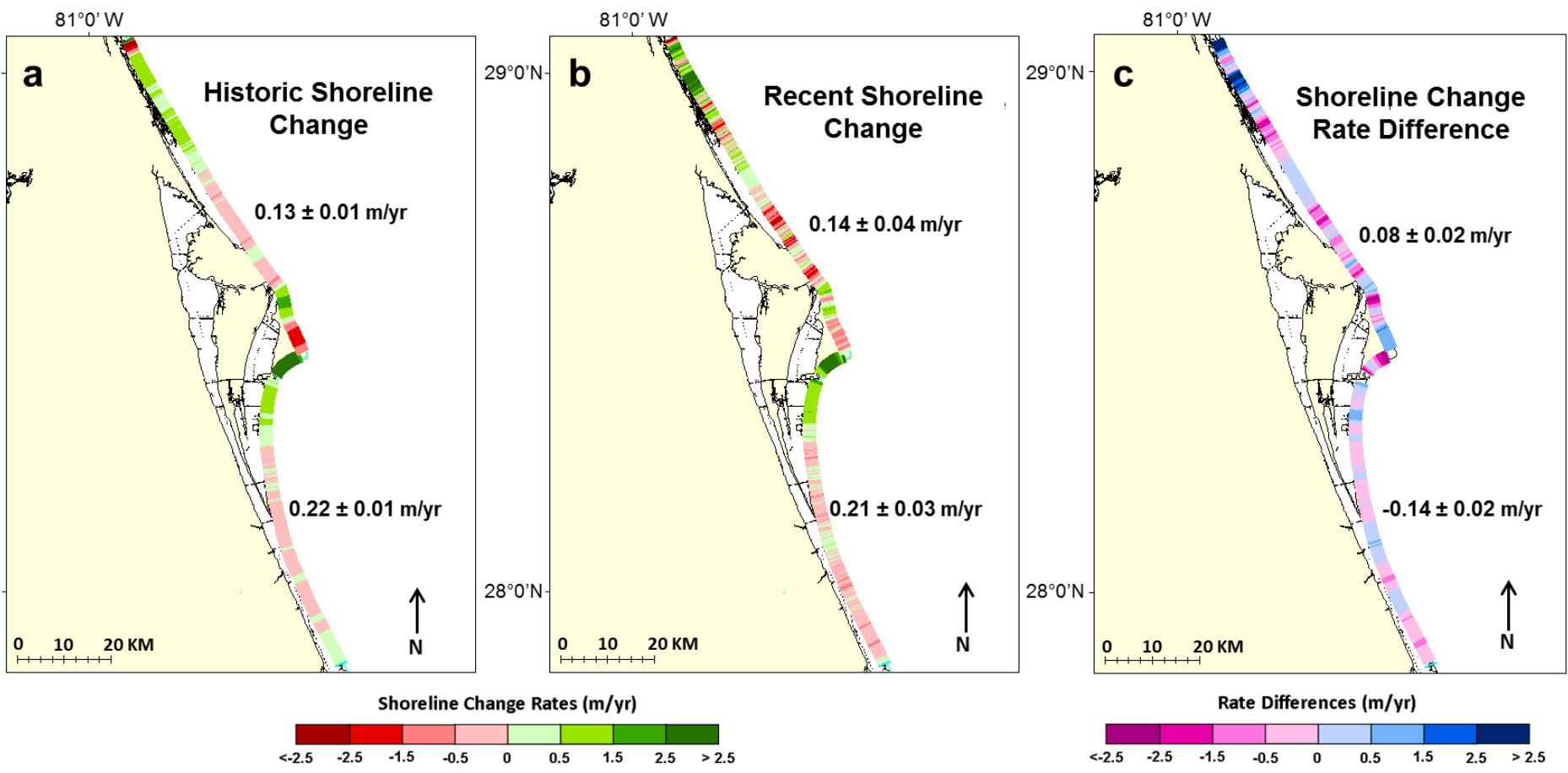

Figure 12. Shoreline change analysis for Cape Canaveral, FL. Colors represent same values as in Figure 9. Shorelines are plotted below rates of change to delineate general coastline trend. 


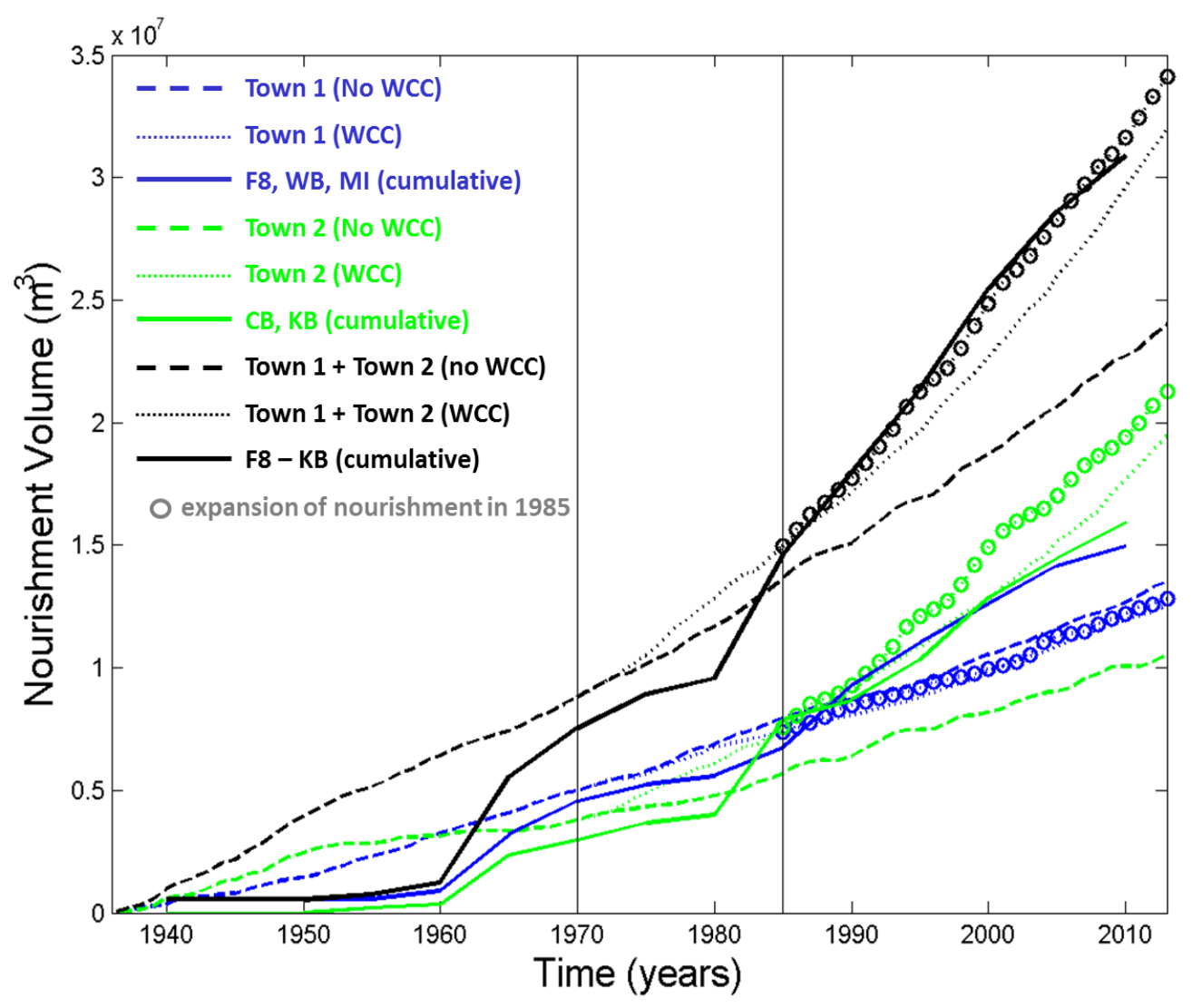

Figure 13. Observed and model-generated cumulative nourishment volumes for the north flank of Cape Fear. Solid black line represents observations of combined nourishment volumes across the study area. The black dashed and dotted lines represent nourishment volumes generated from model simulations without wave climate change (No WCC) and with wave climate change (WCC). The dotted lines with circles overlain indicate nourishment volumes generated from a simulation including WCC and expansion of nourishment after 1985. Blue and green lines indicate observed and model-generated nourishment volumes presented by Town. Town 1 (blue lines) includes Figure Eight (F8), Wrightsville Beach (WB) and Masonboro Island (MI) and Town 2 includes Carolina Beach (CB) and Kure Beach (KB). The vertical lines at 1970 and 1985 reflect the onset of wave climate change and expansion of nourishment respectively. 


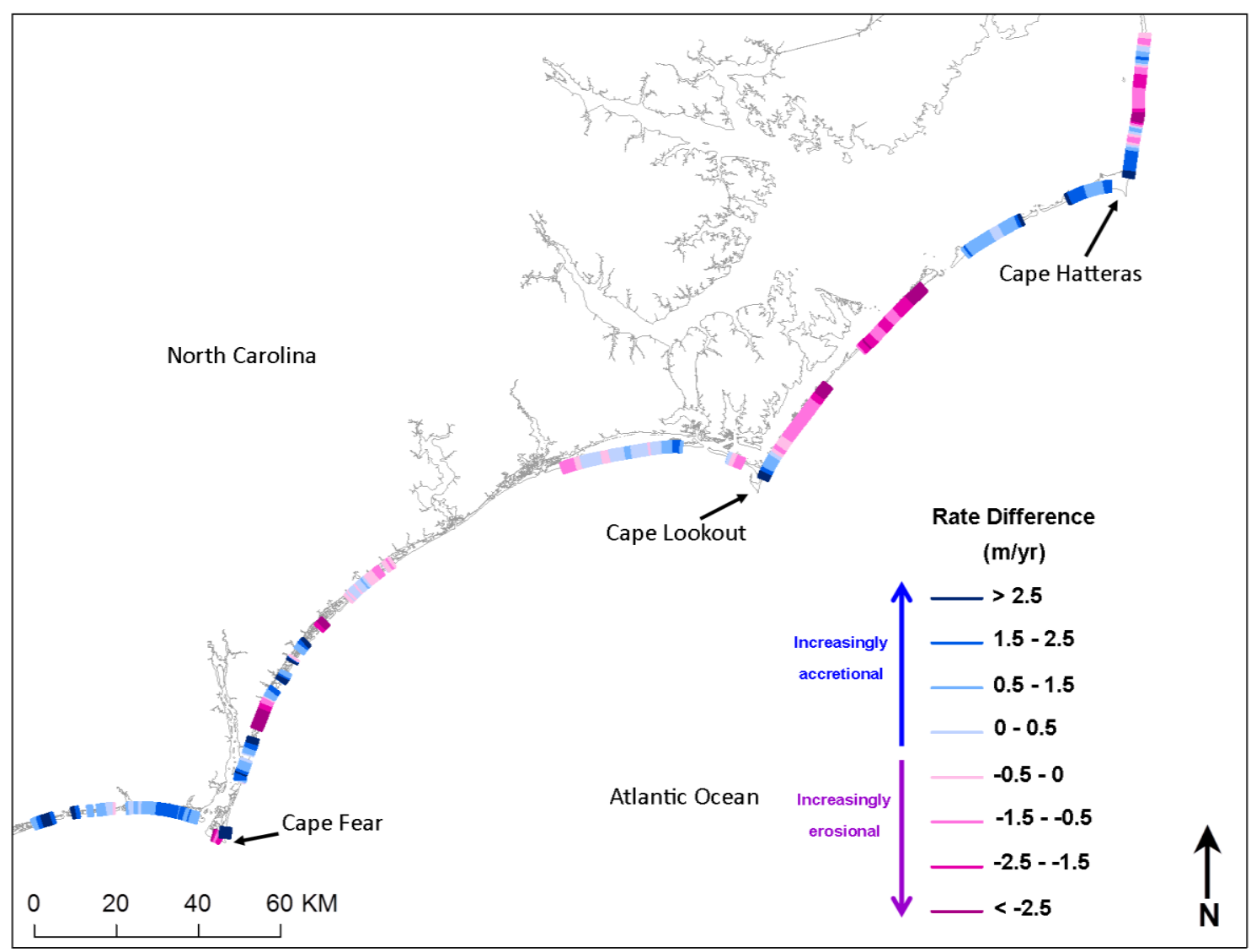

Figure 14. Shoreline change rate differences (SCRDs) for all three North Carolina capes. SCRDs for Cape Hatteras and Cape Lookout indicate the northern flanks have become more erosional/less accretional whereas the southern flanks have become more accretional/less erosional. In contrast, Cape Fear lacks the same erosional signal on the northern flank, with the exception of the area south of Masonboro Inlet, known to have relatively little beach nourishment activity. Data for Cape Hatteras and Cape Lookout from Moore et al. (2013). Data for Cape Fear from Figure 10c, this paper. 